\title{
PROTECTION AGAINST DOG DISTEMPER AND DOGS PROTECTION BILLS: THE MEDICAL RESEARCH COUNCIL AND ANTI-VIVISECTIONIST PROTEST, $1911-1933$
}

\section{E. M. TANSEY *}

The National Insurance Act of 1911 provided, by creating the Medical Research Committee, explicit government support for experimental, scientific medicine. This official gesture was made against a background of concern about some of the methods of scientific medicine, especially the use of living animals in medical research. Organized protests against animal experiments had gathered strength during the middle of the nineteenth century and resulted in the establishment of a Royal Commission to enquire into the practice of subjecting animals to experiments. The recommendations of that Commission led to the passing of the 1876 Cruelty to Animals Act, which governed all experiments calculated to give pain, and carried out on vertebrates. This paper will extend the examination of laboratory science and laboratory animals into a later period, the first decades of the twentieth century. It will focus on the use of one particular animal, the dog, in one specific laboratory, the National Institute for Medical Research (NIMR) in London, and will examine three related themes: the use and justification of the dog in experimental laboratory research into canine distemper at the Institute from its establishment in 1913 until the mid-1930s; this will be set against the protests of anti-vivisectionist groups and their use of the dog as a motif of animal suffering; and the moves by both opponents and proponents of animal experimentation to promote their views and to influence public opinion and members of the legislature.

* E. M. Tansey, BSc, PhD, PhD, Wellcome Institute for the History of Medicine, 183 Euston Road, London NW1 2BE

Whilst this paper was in the press, I learned of the death of Sir William Paton FRS, the distinguished pharmacologist who had been a Wellcome Trustee and honorary Director of the Wellcome Institute for the History of Medicine. I would like to dedicate this paper to his memory, in grateful recognition of the enthusiastic and critically stimulating encouragement he gave me on many occasions.

I am deeply indebted to Mr R. J. Moore, Librarian of the National Institute for Medical Research for his assistance and enthusiastic encouragement during the progress of this research, and to Dr J. J. Skehel FRS, Director of the NIMR for research facilities, for permission to quote from the Institute's records, and for helpful comments on an earlier draft of this paper. For permission to consult and quote from other records I thank Sir Dai Rees FRS of the Medical Research Council; Dr Mark Matfield of the Research Defence Society; and the Committee of The Physiological Society. The archivists of the Contemporary Medical Archives Centre of the Wellcome Institute Library and the library staff of the Wellcome Institute, maintained by the Governors of the Wellcome Trust, have all provided considerable assistance, as have staff in the MRC Head Office, especially $\mathrm{Mr}$ A. R. Helm, Mr P. Toms and Miss D. Torrance. For helpful criticisms of earlier drafts of this paper I thank Professor W. F. Bynum, Dr S. E. Lederer, Dr A.-H. Maehle and Professor Sir William Paton FRS. I am very grateful to Mrs Wendy Kutner for secretarial help and to the Wellcome Trust for financial support. 


\section{THE DEBATES AT THE BEGINNING OF THE TWENTIETH CENTURY}

Much of the disputation and debating about animal experimentation during the Victorian period have been appraised in fine detail by Richard French. ${ }^{1}$ Dogs as experimental subjects were particularly contentious, and the original Bill which gave rise to the 1876 Cruelty to Animals Act specifically excluded cats, dogs, horses, mules and asses from being used in medical research. Strong representations were made during the latter part of 1875 and the beginning of 1876 to reverse this prohibition. The General Medical Council, and the British Medical Association, which organized a petition for readers to sign in the British Medical Journal, campaigned, ultimately successfully, against this exclusion, although these groups of animals were provided with the additional protection of specialized certificates. ${ }^{2}$ Dogs, however, provided potent symbols of innocent suffering for the anti-vivisectionist movement; their close relationship with humans, and their companion status, made the peril of pet-stealing a threat that could regularly be invoked, although evidence of the practice was never forthcoming. ${ }^{3}$ The Victoria Street Society, an anti-vivisectionist organization founded in 1875 as the Society for the Protection of Animals Liable to Vivisection, adopted Edwin Landseer's painting of a dog, A distinguished member of the humane society, as part of their emblem, and the Abolitionist, the organ of the British Union for the Abolition of Vivisection (BUAV), carried repeated appeals "that every dog lover ought to aid the anti-vivisection movement". ${ }^{4}$

During the first decade of the twentieth century, both opponents and proponents of animal experimentation continued to use similar propaganda techniques, producing pamphlets, distributing handbills in the street, and relying on sympathetic Members of Parliament to advise on hostile legislative moves, or to promote favourable Bills. ${ }^{5} \mathrm{~A}$ fresh development during the early 1900 s was the opening of propaganda shops in central

' R. D. French, Antivivisection and medical science in Victorian society, Princeton University Press, 1975. See also the several papers in N. A. Rupke (ed.), Vivisection in historical perspective, London, Croom Helm, 1987.

${ }^{2}$ Additional certificates to work on these groups of animals were granted only to those already authorized to hold licences, for further details of the conditions and procedures see E. M. Tansey, 'The Wellcome Physiological Research Laboratories 1894-1904: the Home Office, pharmaceutical firms and animal experiments', Med. Hist., 1989, 33: 1-41. A comment in Punch contemporary with the passing of the Cruelty to Animals Act, ostensibly from Punch's dog 'Toby', contrasts the numbers of dogs used in experiments, then estimated to be about 20 a year, with the day-to-day cruelties inflicted on dogs by ignorant owners. Toby continues, "Whereas the operations of the vivisector enabled him to solve problems affecting brutes as well as human beings, and to discover secrets, of which the knowledge applied in Medicine and Surgery-veterinary as well as humanrelieved or rescued from the most poignant agonies both men and dogs too." Punch, 1876, 71: 40-44.

${ }^{3}$ Several authors have commented on the special standing of the dog, and the debates about its use in medical research. For example, S. E. Lederer, 'Political animals: the shaping of biomedical research literature in twentieth-century America', Isis, 1992, 83: 61-79, examines the use of dogs and subsequent reporting of experiments in the J. exp. Med. during the mid-part of the twentieth century; J. C. Russell and D. C. Secord, 'Holy dogs and the laboratory: some Canadian experiences with animal research', Perspec. Biol. Med., 1985, 28: 374-81, reports more recent events, also in a North American context. The frequent taunts of pet-stealing seem to have little actual substance, apart from the case of two dogs in 1926 reported below, and an incident involving stolen cats in Bedford in 1905, see Chem. \& Drug., 1905, 66: 348.

${ }^{4}$ For example, the Abolitionist, 1913, 14: advertisement following p. 120.

${ }^{5}$ Representatives from the two sides of debates frequently clashed. For example, at its meeting of 17 Nov. 1911, the Animal Defence and Anti-Vivisection Society passed a motion that the Commissioner of Police be asked to remove men who were distributing Research Defence Society leaflets outside 169 Piccadilly where the Society was holding an 'Animals Christmas Bazaar'. The Animal Defence and Anti-Vivisection Society Minutes of Executive Council 1911-1916, in the Contemporary Medical Archives Centre, the Wellcome Institute for the History of Medicine (henceforward CMAC), CMAC GC/52. 


\section{The Medical Research Council and anti-vivisectionist protest}

London and in other towns and cities by several anti-vivisection societies. These usually contained prominent displays of stuffed animals, typically cats or dogs, tied down, with gags in their mouths. ${ }^{6}$ The crudity of these exhibits often caused considerable offence to medical scientists and their representatives, the Research Defence Society, and to members of the general public. ${ }^{7}$ In response to a demand in the House of Commons in 1912 for their closure, the Home Secretary regretfully acknowledged that he had "no power to prevent such displays". 8 After much ineffectual complaint at the practice, the Research Defence Society decided that they too would open a shop for handbills and pamphlets at 151 Piccadilly, London, in an adjacent building to an anti-vivisectionist shop. ${ }^{9}$

Attempts by animal welfare groups and anti-vivisectionist societies to influence public opinion and to alter the law continued long after the passage of the 1876 Act. In 1903 libellous allegations by two Swedish women, Liesa von Schartau and Louise Lind-afHageby, that a dog was cruelly used in an experiment at University College London, the so-called "Brown Dog" affair, led to clashes in the streets of central London when anti-vivisectionists tried to erect a memorial to the animal. ${ }^{10}$ Three years later, the Dogs Act of 1906 was passed, which, amongst other provisions, made it illegal for stray dogs to be offered or sold for the purposes of "vivisection", a move which aroused no comment in the medical press. " Both pro- and anti-vivisectionists gave evidence to the Second Royal Commission on Animal Experimentation, which sat from 1906 until 1912, when it reported that strong arguments had been presented for the complete exemption of dogs from experimental procedures. Its members were, however, also impressed by scientific witnesses such as Sir William Osler, who advocated the continuing necessity of using dogs,

... and he [Osler] quoted with approval the opinion of Dr Cushing to the effect that: 'There

is naturally a feeling of regret in the minds of many — of none greater than our own-that

\footnotetext{
${ }^{6}$ The British Union for the Abolition of Vivisection, the National Anti-Vivisection Society, and the Animal Defence and Anti-Vivisection Society all maintained shops. The Abolitionist frequently published photographs of such shops, although many appear to have been opened for only a brief period in short-lease premises. Some, e.g. in Nottingham, also contained a cafe, which may have contributed to their popularity: Abolitionist, 1913, $14: 81$.

${ }^{7}$ A pamphlet by the Research Defence Society, The facts of the case, May 1912, rails at the deception that encouraged innocent bystanders to believe that animals were operated on without anaesthetics, CMAC/SA/RDS/ G1/28. Some premises were physically attacked, e.g. an anti-vivisectionist shop in Edinburgh was assaulted by medical students, RDS Quarterly report, 1913, p. 6. Many years later, the RDS`s concern at these displays was mitigated by a consideration of the cost of maintaining the premises, and the fact that the crude moth-eaten exhibits defeated the BUAV's purpose, CMAC/SA/RDS, 1938 Minutes Book.

${ }^{8}$ The Times of 11 June 1912 reports the Question by Sir Philip Magnus, objecting to the bright red anti-vivisectionist shops in Piccadilly and Oxford Street, CMAC/SA/RDS/G1/28.

"RDS Quarterly report, Jan. 1913. The Animal Defence and Anti-Vivisection Society thanked their landlord, Mr Marks, for not allowing the RDS to acquire their premises in Piccadilly, meeting of 3 Feb. 1913, the Animal Defence and Anti-Vivisection Society, Minutes of Executive Council 1911-1916, CMAC/GC/52.

${ }^{10}$ For accounts and interpretations of this affair, see, e.g., L. E. Bayliss, 'The "Brown Dog" affair', Potential (the journal of the Physiology Society of University College), 1957, 2: 11-22; J. H. Baron, 'The brown dog of University College', Br. med. J., 1956, ii: 547-8; C. Lansbury, The old brown dog, Madison, University of Wisconsin Press, 1985.

"This Act remains on the statute books, in contrast to the situation in the USA where pound animals can and could be offered for medical research purposes. See Lederer, op. cit., note 3 above, pp. 65-6, and A. E. Clark, 'Research materials and reproductive science in the United States 1910-1940', in Physiology in the American context, 1850-1940, ed. G. Geison, Bethesda, American Physiological Society, 1987, pp. 323-50, especially p. 335, for discussions of the American situation. See also M. Young, 'The stray dog problem', in Pet animals and society, ed. R. S. Anderson, London, Baillière Tindall, 1975, pp. 103-7, for a British comment. The 1876 Act
} 


\section{E. M. Tansey}

animals, particularly dogs, should thus be subjected to operations, even though the object would be a most desirable one and accomplished without the infliction of pain, and did expense permit we would gladly have used animals with which there is an association of less acute sentiment on the part of all. ${ }^{12}$

No restrictive action was proposed in the final majority report produced by the Royal Commission in 1912. ${ }^{13}$ Whilst the Commission was sitting, in 1908 and again in 1910, Dogs Protection Bills, to exempt dogs completely from animal experimentation, were introduced into Parliament, although both were unsuccessful. These attempts to pass what they regarded as even more restrictive legislation stimulated the Research Defence Society and the British Medical Association into action. Their strategies were broadly similar to those adopted in earlier debates. ${ }^{14}$ In 1913, in the wake of the Royal Commission's report, yet another Dogs Protection Bill was proposed. After its first reading in the House of Commons, the Bill's backers realized that it had a chance of succeeding, and tried to dissuade Sir Philip Magnus MP, one of the Bill's fiercest critics, from his arguments. They offered a proposal that would permit some limited experiments on dogs, under carefully defined circumstances and with special licensing conditions. Magnus referred the offer to the BMA's Medico-political Committee, which concluded that it was unsatisfactory, and Parliamentary opposition to the Bill was renewed. ${ }^{15}$ Simultaneously, articles and pamphlets were produced to explain and promote the medical benefits of experiments on dogs. One leaflet, by Ernest Starling, Professor of Physiology at University College London, dismissed any distinction between "utilitarian" and "pure" research, declaring that all research was ultimately utilitarian. He enumerated, from his own research experience, an extensive range of knowledge, including that of lymph production, cardiovascular function and gastrointestinal physiology, that had been derived principally from experiments on dogs. ${ }^{16}$ Starling suggested that

had made no provisions about the supply of animals; experimenters had to procure animals by any lawful means, which rendered them susceptible to inadvertent purchase of stolen animals, as happened in 1926, see page 19 below.

12 'Paragraph 118. Experiments on dogs and certain other animals', Final report of the Royal Commission on Vivisection [Cmnd 6114], London, HMSO, 1912, pp. 62-3.

${ }^{13}$ Despite occasional questions about distemper during the course of the Commission, there is no mention of canine distemper in the final report although twelve paragraphs deal with diseases in animals, see, ibid., pp. 43-6. I thank Sir William Paton for drawing the relevant passages to my attention.

14 The BUAV Annual report for 1912 included in its membership list 43 MPs and 3 members of the House of Lords as "Parliamentary vice-presidents". Similarly, the RDS had members of the legislature amongst its members, and its chairman was Lord Knutsford. The BMA's Parliamentary Sub-Committee, with a brief to report on matters affecting members of the medical profession, frequently alerted the membership of Bills concerning animal experimentation, see 'Vivisection: Dogs Protection Bills, minutes and cuttings, 1908-1949', CMAC/SA/BMA/C87.

${ }^{15}$ Quarterly report of the Medico-political Committee to BMA Council, Oct. 1913, Item 8, Dogs Protection Bill, Minute 14: "Every session for some time past the Dogs Protection Bill has been introduced ..." begins the report, which refers to the other authorities, including the BMA's Science Committee, that were consulted before the recommendation was made, see 'Vivisection: Dogs Protection Bills, minutes and cuttings, 1908-1949', CMAC/SA/BMA/C87.

${ }^{16}$ Much of Starling's research on integrative mechanisms in cardiovascular and gastrointestinal physiology was performed on anaesthetized dogs, see, e.g., E. B. Verney, 'Some aspects of the work of Ernest Henry Starling', Ann. Sci., 1957, 12: 30-47, and C. B. Chapman, 'Ernest Henry Starling', Dictionary of scientific biography, ed. C. C. Gillispie, 16 vols, New York, Scribner, 1970-1980, vol. 12, pp. 617-19. 
... any legal prohibition of the use of dogs for experimental purposes would deal an irremediable blow to physiology and medicine, the only practical result of which would be a few hundred more to be killed in the lethal chamber at Battersea. . .

and stressed that 20,000 strays were annually destroyed at the Battersea Dogs' Home. ${ }^{17} \mathrm{He}$ did not, at that juncture, suggest that such dogs be made available for experiments, although that argument was advanced at a later date (see page 21 below). During the same period, another prescient proclamation appeared in the Research Defence Society's literature: "We must remember, also that dogs often die of distemper. The only way to find how to protect dogs against that disease, must be by experiments on dogs." 18

\section{THE MEDICAL RESEARCH COMMITTEE 1913}

A fresh, and substantial, challenge to opponents of animal research was the National Insurance Act of 1911, a lengthy and complex piece of legislation that included a "research" clause. This allowed for the apportioning of some of the insurance revenue for the purposes of research, and eventually led to the creation of the Medical Research Committee, later the Medical Research Council (the abbreviation MRC will be used for both bodies). ${ }^{19}$

This proposal, widely publicized in the popular press, caused outrage in antivivisectionist circles, always on the alert to the promotion of experimental medicine. ${ }^{20}$ Letters to the general press and in their own publications expressed disgust at the concept, outrage at the appointment of known vivisection sympathizers such as Lord Moulton to the Medical Research Committee, and anger at the amount of money, about $£ 57,000$ in the first year, to be expended on the scheme. ${ }^{21}$

One immediate, and perhaps unexpected, effect of the National Insurance Act was to foster some degree of unity between the various anti-vivisectionist groups, which, despite apparently similar aims, had such diverse agenda that they were rarely able to co-operate. But faced with state endowment for medical research they joined in several protests. One of the most dramatic was a demonstration in Central London on 28 October 1913 against the research clause in the National Insurance Act. A procession from the Embankment to

${ }^{17}$ E. H. Starling 'On the use of dogs in scientific experiments', RDS (c. 1912-1913), CMAC/SA/RDS/G1/24.

${ }^{18}$ Research Defence Society, Experiments on dogs, June 1910, emphasized that dogs and cats were principally used in experiments under total anaesthesia and very seldom for procedures performed without anaesthetics, usually inoculations or injections, CMAC/SA/RDS/G1/16.

${ }^{19}$ For the creation and early history of the MRC, see A. L. Thomson, Half a century of medical research, 2 vols, London, HMSO, 1973 and 1975; and the essays in J. Austoker and L. Bryder, Historical perspectives on the role of the MRC, Oxford University Press, 1989.

${ }^{20}$ For example, "This move will need careful watching" was the Abolitionist's comment after a meeting of the General Medical Council on 28 Dec. 1912, which had included a resolution by Sir Clifford Allbutt about securing adequate financial support for research, Abolitionist, 1913, 14: 9. Similar fears were expressed several years later over the creation of the NHS, e.g., National Health Service and vivisection, 1947, published by the Kent branch of the British Union for the Abolition of Vivisection.

${ }^{21}$ For example, 'A "Scheme" without a scheme', complained that nearly $£ 60,000$ was to be spent, Abolitionist, 1913, 14: 169; the same issue contained a virulent attack on Lloyd George's committee and the appointment of Lord Moulton, considered to be a supporter of animal experimentation, as its chairman, ibid., 174-5. As a consequence of the BUAV's 1912 AGM, their Parliamentary representative Mr Chancellor approached Lloyd George on behalf of 17 other anti-vivisectionist societies, but failed in his representation to remove the "research clause" from the Bill, BUAV Annual report, 1912, p. 6. 
Hyde Park concluded with speeches from several platforms, ${ }^{22}$ with medical practitioners prominently identified amongst the speakers by the anti-vivisectionist press, an emphatic claim that opponents to medical research could themselves be professional medical men, with the care of patients at heart. ${ }^{23}$

\section{THE NATIONAL INSTITUTE FOR MEDICAL RESEARCH}

However, it was not until 1914 that direct and persistent anti-vivisectionist activity was proposed. This was the result of a very early decision made by the MRC in July 1913, that "a central Bureau with rooms for laboratories attached should be obtained. A central staff must be organised at the earliest moment both as regards office and lab work."24

This was to be in or close to London. ${ }^{25}$ The need for such an institute was regularly reiterated at the Medical Research Committee's monthly meetings, the Minutes of which reveal detailed discussions about the nature of the research to be supported, and the recruitment of the personnel to perform that research. ${ }^{26} \mathrm{~A}$ scheme of four departments, one of Statistics, and three research units, of Biochemistry and Pharmacology, of Applied Physiology, and of Bacteriology, was finally approved. Relevant staff were considered, approached and appointed, and at the end of 1913 the MRC purchased the Mount Vernon Hospital for Consumptives in Hampstead, North London, for conversion into laboratories. ${ }^{27}$ The use of a former hospital as a place of animal experimentation brought forth particularly vociferous complaints in the anti-vivisectionist press. ${ }^{28}$

The Honorary Secretary of the Animal Defence and Anti-Vivisection Society, the same Miss Lind-af-Hageby of the "Brown Dog" affair, saw an excellent opportunity for a fresh anti-vivisection campaign, as the Society's Minutes reveal:

22 Abolitionist, 1913, vol. 14, contains several announcements, reports and photographs of the demonstration, see, e.g., pp. 232-6; and the BUAV Annual report, 1912, p. 10.

${ }^{23}$ An active campaign was organized to recruit medically qualified persons to speak on behalf of antivivisectionist groups, see the Abolitionist, 1914, 15: 147. Although the scientific achievements of antivivisectionist doctors, such as the academic record of Dr Walter Hadwen, the Director of the BUAV, were sometimes stressed when considered appropriate, most of those identified in sources such as membership lists are recorded as general practitioners, again emphasizing their direct contact and concern with patients, compared with the more remote, elite medical research scientists.

${ }^{24}$ MRC meeting, 24 July 1913. The need for an institute was reinforced at the next meeting on 22 Oct., when "[I]t was agreed that a Central Institute in London itself was a sine qua non of the work of the committee-also that efficient laboratories should be installed. A staff of skilled observers must be obtained and a careful review made of possible men“. Both in MRC Minutes Book I, 1913-1914, in the Archives of the Medical Research Council, henceforward MRC Archives, which are in the process of being transferred to the Public Record Office.

25 ." It was ] unanimously agreed that the Central Institute must be in or very near London. Not only should it be of easy access to the Committee, but it should ensure that the workers were continually in touch with the centres of thought”. MRC meeting, 30 Oct. 1913, MRC Minutes Book I, 1913-1914, MRC Archives.

26 Thomson, op. cit., note 19 above, vol. 1, pp. 108-9, suggests that the MRC was strongly influenced by ventures such as the Rockefeller and the Pasteur Institutes. Colonel Sir William Leishman, a member of the Committee, visited several North American sites, including the Rockefeller, the Johns Hopkins Medical School, and McGill and Toronto Universities, to inspect and report on their facilities and organization, Minutes of meeting, 19 March 1914, Minutes Book I, 1913-1914, MRC Archives.

27 The estimated costs were $£ 35,000$ for the building (the owners accepted a cash payment of $£ 11,000$, and four annual payments of $£ 6,000)$ with additional capital expenditure of $£ 2,000$ for the Library. Annual running costs for the Institute were estimated at $£ 20,000$. MRC meetings, 20 Nov. 1913, 11 Dec. 1913, MRC Minutes Book I, 1913-1914, MRC Archives.

${ }^{2 \times}$ See, e.g., the quote on p. 12 referred to in footnote 61 below. 


\section{The Medical Research Council and anti-vivisectionist protest}

The Hon Secretary [LafH] placed several important suggestions before the Council in view of the announcements recently made that Mount Vernon Hospital in Hampstead was to be utilised as a place for animal experimentation under the National Insurance Act. This circumstance afforded an excellent opportunity for starting a vigorous anti-vivisection campaign. She suggested starting a special advertisement campaign, inserting large \& effective advertisements in the large daily papers, giving quotations of admissions made before the Royal Commission on Vivisection, and urging the men and women of England to protest against being forced to contribute under the Insurance Act to cruel experiments on animals. She further suggested that effective posters should be displayed on the hoardings of London and that a vigorous campaign for the distribution of leaflets in the streets be organised. Possibly sandwich processions would also be of use. Further a public protest meeting ought to be held in Hampstead after the opening of Parliament. In order to make these schemes possible it would be necessary to issue a special appeal for funds. ${ }^{29}$

The proposal was readily accepted, and an immediate appeal launched for funds to mount a suitable crusade and to prepare a new campaigning leaflet. ${ }^{30}$ In an early example of shrewd media tactics, Lind-af-Hageby gave an interview to the Daily Mail, supplemented by a large advertisement for the Society in the paper on the same day. A public protest meeting was held in Hampstead Town Hall on $10 \mathrm{March}$, attended by 60 residents, and resolutions objecting to the Institute were passed and sent to the Chancellor of the Exchequer, Lloyd George, the instigator of the Act. ${ }^{31}$ At the end of that month, a unified Anti-Vivisectionist Conference was held at Caxton Hall to discuss parliamentary policies and to co-ordinate activities. Several representatives, including Lind-af-Hageby, were also invited to attend a meeting in the House of Commons on 2 April to explain their objections to the National Insurance Act and its research implications. ${ }^{32}$

The onset of the First World War severely disrupted the plans of the MRC to establish their National Institute, and also quietened the protests of the anti-vivisectionists. Mount Vernon Hospital was handed over to the War Office for use as a military hospital. ${ }^{33}$ The Abolitionist, ever ready to criticize, complained that the hospital should, under the National Insurance Act, be for the benefit of all insured persons, not merely for military personnel. ${ }^{34}$

\footnotetext{
${ }^{29}$ Minutes of a meeting held $15 \mathrm{Jan} .1914$, in 'The Animal Defence and Anti-Vivisection Society, Minutes of Executive Council 1911-1916, CMAC/GC/52.

30) At the next meeting, Lind-af-Hageby reported that enquiries had confirmed that Mount Vernon Hospital was to be devoted to vivisection, and she quoted Lloyd George's statement that the National Insurance Act would support experimental work on animals. Meeting of 7 Feb. 1914, ibid. See also Parliamentary Debates, vol. 55 , col. 411, 9 July 1913. See p. 26 for the particular relevance of the Brown Institute in the debate about experiments into animal disease.

${ }^{31}$ Hampstead, unusually, already had its own Society for the Protection of Animals, devoted to the care of animals on Hampstead Heath and working animals, straining on Hampstead's hills. Its residents may therefore have been especially receptive to claims made by the anti-vivisectionists. Certainly, a local branch of the BUAV was readily established there in 1913.

32 Minutes of meeting, 27 Jan. 1914, in 'The Animal Defence and Anti-Vivisectionist Society, Minutes of Executive Council 1911-1916', CMAC/GC/52.

${ }^{33}$ Negotiations had been initiated with the Lister Institute to amalgamate the two organizations, although the MRC resolved to keep the Mount Vernon premises, even if the association succeeded, which it did not, see N. Morgan, 'A note on the proposed amalgamation of the Lister Institute of Preventive Medicine and the Medical Research Committee: philanthropy and state support of medical research, 1914', Ann. Sci, 1986, 43: 287-9. At the outbreak of war, the MRC offered the building to the War Office, which then assigned it to the 2nd Canadian Stationary Hospital. MRC meeting, 8 Oct. 1914, Minutes Book I, 1913-1914, MRC Archives.

${ }^{34}$ Abolitionist, 1916, 17: 218-19.
} 


\section{E. M. Tansey}

By the outbreak of war, the MRC had already appointed its key research staff and they were consequently housed in temporary accommodation across London, and their time and resources were devoted to schemes associated with the war. For the next four years, Henry Dale's department of Biochemistry and Pharmacology was accommodated in the Lister Institute. The work there concentrated on manufacturing and testing replacements for pharmaceuticals previously obtained from Germany, especially the anti-syphilitics Salvarsan and neo-Salvarsan; and Dale also made an extensive series of studies on amoebic dysentery and its chemotherapeutic treatments. ${ }^{35}$ These experiments in particular were seized upon by anti-vivisectionists, who described the MRC's annual reports as "an annual orgy of cruelty and tomfoolery", and criticized the research undertaken, the reasons for it, the facilities provided, and the "exorbitant salaries" paid to the research staff. The work of Dale and his colleagues on Salvarsan derivatives was described as "sinister", and the amoebic dysentery experiments, which resulted in an effective treatment for a disease rife in the trenches, were dismissed as "idiotic". At a time when the national press was lauding the work in the context of vital war work, such opinions and their expression were seen to be unpatriotic, and the anti-vivisectionists lost support. ${ }^{36}$

By this stage they were having difficulties. The British Union for the Abolition of Vivisection concentrated its energies on an anti-vaccination campaign aimed at "protecting" service men. Their rhetoric depicted a military recruit resisting inoculation as an innocent victim of science, analogous to the tortured laboratory animal. ${ }^{37}$ But these tactics met with considerable public disapproval and the strategy was seen as essentially disloyal, even treacherous, and a danger to British fighting forces. The Union lost support at both national and local levels, and all branch meetings were suspended. ${ }^{38}$ Simultaneously, some anti-vivisectionist organizations protested at a press boycott of their letters, which forced them to pay for expensive advertisements, which were in turn frequently cancelled by the newspapers. ${ }^{39}$ The Animal Defence and Anti-Vivisection Society as their name suggests, had a slightly wider remit, and concentrated their wartime protests on conditions for military horses. However, the extensive promotion of anti-toxin therapy by the military medical authorities did sting them into reissuing their pre-war Anti-Vivisectionist Review. ${ }^{40}$

${ }^{35}$ See E. M. Tansey, 'Sir Henry Dale’s laboratory notebooks, 1914-1919’, Med. Hist., 1990, 34: 199-209, most of Dale's experiments were on rodents and cats.

${ }^{36}$ See, for example, the Abolitionist, 1914, 15: 258-9.

${ }^{37}$ BUAV Annual report, 1916, p. 1. For a wider discussion of the politics of anti-vaccination movements, see $R$. M. MacLeod, 'Law, medicine and public opinion: the resistance to compulsory health legislation, 1870-1907', Public Law, 1967, summer: 106-28, 188-211; and Dorothy Porter and Roy Porter, 'The politics of prevention: anti-vaccinationism and public health in nineteenth-century England', Med. Hist., 1988, 22: 231-52.

${ }^{38}$ The BUAV Annual report, 1915, pp. 8-9, reported that several provincial branches had temporarily withdrawn from practical involvement because of members' other preoccupations, and that the loss was seriously felt. An attempt to express their message in more appropriate language for the period is revealed in a denunciation of the "Hun of the laboratory", Abolitionist, 1914, 15: 258-9. See also the quote referred to in note 39 below.

${ }^{39}$ Abolitionist, 1915, 16: 4, claimed that The Times, Daily Mail, Daily Telegraph, Daily Graphic and Daily Express refused their advertisements and letters due to the malignant influence of vivisectors, "each one is a little kaiser". Ibid., p. 33, prints a copy of a private and confidential letter from the Press Bureau to editors, warning that the BUAV was circulating a dangerous notice calculated to deter men offering their services and which should not be encouraged. See also the BUAV Annual report, 1915, p. 11; and ibid., 1917, p. 4, complaining of Press and War Office support for vivisection. Almost identical claims of censorship were levelled years later at the British Broadcasting Company, e.g., letter to Sir John Reith, Abolitionist, 1930, 31 : 54.

+o) For example, Minutes of meeting, Sept. 1914, 'The Animal Defence and Anti-Vivisection Society Minutes of Executive Council 1911-1916', CMAC/GC/52. 


\section{The Medical Research Council and anti-vivisectionist protest}

Similarly the Research Defence Society's activities were muted, they engaged in no new campaigns and published no new leaflets. ${ }^{41}$ They did reissue earlier pamphlets on antitoxin treatment, with the insertion of official hospital statistics from the British Expeditionary Force in France extolling the benefits of anti-tetanus and anti-typhoid serum, and did achieve a great deal of civilian and military publicity. ${ }^{42}$ The BUAV countered immediately that these misleading reports were "little short of a public scandal", and demanded that the War Office appoint an independent statistician, not someone employed by the despised MRC. ${ }^{43}$

In 1916, the Research Defence Society's annual report suggested, somewhat overconfidently, that because anti-vivisectionist societies had been discredited since the beginning of war, they might never recover a hold on public opinion. By 1918, clearly dissuaded from protesting about British laboratories, the Abolitionist had started a series of articles entitled 'Rockefeller hell', reporting on conditions in the Rockefeller Institute in New York. ${ }^{44}$ Very soon they were to have an opportunity to recover their pre-war hold on public opinion and to protest at the Rockefeller Institute's British equivalent, when the National Institute for Medical Research finally became a physical reality in Hampstead in 1919.45

The end of international hostilities reopened those between animal experimenters and anti-vivisectionists. An early salvo in the renewed campaign was another Dogs Protection Bill and an early battle ground was the National Institute for Medical Research. ${ }^{46}$ A Bill exempting dogs from experiments was proposed in 1919 and in a society weary of war and slaughter, it passed through several stages in the House of Commons. ${ }^{47}$ Many sections of the medical and scientific community realized that this time it might become law. ${ }^{48} \mathrm{~A}$ determined lobby of the Government was organized by the Medical Research Council ${ }^{49}$

\footnotetext{
${ }^{41}$ Undated draft account of wartime activities included in an envelope of miscellaneous correspondence etc. in CMAC/SA/RDS/C2, Minute Book, 1920-1948. The RDS, with the support of the Army Medical Department, provided lecturers for troops, many co-ordinated or given by Dr Charles Saleeby, see R. S. Vine, 'The history of the Research Defence Society', Conquest, 1987, 176: 10-16.

${ }^{42}$ CMAC/SA/RDS/G1/30, Jan. 1916, a re-issued 1914 leaflet about typhoid fever, lists official admission statistics from the Expeditionary Force in France and Belgium, these leaflets were also published in French. G1/32(1), 'Scientific medicine and the expeditionary force', was reprinted from the Field, 8 April 1916; G1/36, 'The prevention of tetanus during the great war by the use of anti-tetanic serum'.

4.3 BUAV Annual report, 1916, p. 8.

44 'The Rockefeller hell', Abolitionist, 1918, 19: 44, also pp. 176, 187.

${ }^{45}$ Some urgency was expressed that the Institute should be fully operational as soon as possible after the end of the war, and the MRC's concern was passed to the Air Council, then occupying Mount Vernon Hospital. MRC meeting, 3 Jan. 1919, Minute 2, 'Central Research Institute', MRC Minutes Book II, 1915-1926, MRC Archives.

${ }^{46}$ MRC meeting, 7 April 1919, Minute 67, 'Protection of Dogs Bill'. The MRC decided to submit a memorandum to the Minister for the information of Parliament. MRC Minutes Book II, 1915-1926, MRC Archives.

${ }^{47}$ The new action also followed a general election during which anti-vivisectionist branches and journals had particularly urged newly-enfranchized women to vote for candidates they endorsed, e.g., Abolitionist, 1918, 19: 202.

${ }^{48}$ The BUAV Annual report for 1920 reported an active year and increased membership across the country. One indication of the surge of anti-vivisectionist support was the increase in size of both the Abolitionist and the BUAV Annual report.

${ }^{49}$ MRC meeting, 2 May 1919, Minute 93, 'Dogs Bill', discussed a draft memoradum, subsequently approved and published, 'Memoradum upon the Dogs Protection Bill', Medical Research Committee, London, HMSO, 1919. By the next meeting of the MRC, 30 May 1919, Minute 108, 'Dogs Bill', the Government had announced its opposition to the Bill. Both in MRC Minutes Book II, 1915-1926; memorandum in MRC Report Book I, 1913-1928, p. 200, all in MRC Archives.
} 


\title{
E. M. Tansey
}

and the British Medical Association. Several sections of the BMA passed, unanimously, a resolution, addressed to the Home Secretary, expressing their dismay at the Bill's progress and emphasizing

The prohibition of experiments upon dogs would, in the opinion of this meeting, have the deplorable result of hampering the progress of medicine and of rendering Britain alone, among the civilised nations of the world, unable to contribute to progress in a department of medical research in which it has hitherto played a distinguished part. ${ }^{50}$

Many of the arguments put forward against the Bill included reference to wartime medical research, exemplified by Nature:

\begin{abstract}
After the brilliant successes achieved during the war by physiological and scientific medicine in the preservation of life and the prevention of suffering in our armies, it might have been thought that the agitation against medical experiments on animals would have received its death blow. ${ }^{51}$
\end{abstract}

The combined efforts of the medical profession and medical research scientists persuaded the Government to oppose the Bill, which they did after proposing a series of amendments. ${ }^{52}$ The following year however, Sir Frederick Banbury reintroduced his original, unamended Bill of 1919. This too failed. ${ }^{53}$

\section{NATIONAL INSTITUTE FOR MEDICAL RESEARCH, HAMPSTEAD ${ }^{54}$}

In Hampstead, in 1920, the research staff gradually assembled in the newly refurbished Institute. Early in that year, members of the Hampstead branch of the BUAV organized a concerted campaign against the Institute. Co-ordinated by one Mrs Geraldine Webber, leaflets hinting at the intended work of the Institute, and suggesting that its presence would

\footnotetext{
51) Resolutions forwarded to the Home Secretary, 25 April 1919. The sections of medicine, pathology and preventive medicine supported the resolution proposed by Sir William Osler, seconded by C. J. Martin. Simultaneously the section of surgery approved the motion, proposed by Sir William Bayliss and seconded by $\mathrm{H}$. H. Dale. Reports in the Minutes of the BMA Medico-political committee, 4 June 1919, 'Vivisection: Dogs Protection Bills: minutes and cuttings 1908-49', CMAC/SA/BMA/C.87.

51 'The use of animals in medical research', Nature, 1919, 10: 108-9. Lederer, op. cit., note 3 above, has documented the creation in 1946, and subsequent histories of the Whipple Prize for dog participants in medical research, and the Research Dog Hero Award made by the National Society for Medical Research, see ibid., pp. 73-4. I have not come across any equivalent British gesture during the period under review here.

52 The BUAV Annual report for 1920 contained a bitter attack on the Government's action in defeating the 1919 Bill. The history of that Bill, and its successor, is summarized in Br. med. J., 1920, i: 301-2.

${ }^{5.3}$ See, e.g., 'The Dogs Protection Bill', Br. med. J., i: 448. See also ibid., p. 512, about tentative moves to produce a similar Bill in the United States Senate. The Research Defence Society, which adopted a low profile during the previous year, sent a deputation led by Sir William Bayliss to the Home Office on 17 March 1920 to discuss the role of dogs in medical research, CMAC/SA/RDS/C2, Minutes Book, 1920-1948.

${ }^{54}$ Historical accounts of the NIMR are given by Thomson, op. cit., note 19 above, vol. 1, pp. 108-32; J. Austoker and L. Bryder, 'The National Institute for Medical Research and related activities of the MRC', in Austoker and Bryder, op. cit., note 19 above, pp. 35-57. Directors and other staff of the NIMR have also presented their own reports, see, e.g., H. H. Dale, 'The work of the National Institute for Medical Research', Lancet, 1921, ii: 112-13; C. H. Harrington, 'The work of the National Institute for Medical Research', Proc. R. Soc. Lond. B., 1949, 136: 333-48; P. B. Medawar, Memoir of a thinking radish, Oxford University Press, 1988, especially 'The National Institute for Medical Research', pp. 144-79.
} 


\section{The Medical Research Council and anti-vivisectionist protest}

lower local property values, were delivered to every house. ${ }^{55}$ Similar work was organized by the Finchley and Muswell Hill branch of the BUAV, and a large area of North London received the pamphlets. Regular local meetings were organized and the Abolitionist reported, "There is no doubt that the Institute (which is the Headquarters of the Medical Research Committee) has become highly unpopular in the neighbourhood." 56

At the beginning of April, the laboratory most distinctly connected with animal experimentation, Henry Dale's department of Biochemistry and Pharmacology, moved into the NIMR, and just six weeks later a petition was delivered to the Institute from local residents, complaining of a barking dog. This was also organized by Mrs Webber, and regular letters on the subject appeared in the local press. The complaints reached the House of Commons when Colonel Burns, MP, asked the Home Secretary about a howling dog at Mount Vernon Hospital. The Secretary of State reminded the House that the hospital was now a medical research institute, legally registered with the Home Office for animal experimentation. ${ }^{57} \mathrm{He}$ reported that an internal enquiry had revealed that although a dog had been on the premises for a part of the period complained of, it had not been heard by staff working in accommodation adjoining its quarters. He concluded that the residents had been mistaken in the direction from which they thought the barking came. ${ }^{58}$

The Home Secretary's reply fuelled local indignation, and anti-vivisectionist groups renewed their protests against the Institute. The BUAV immediately organized a "Special Propaganda" open-air meeting at Hampstead to complain about the Home Secretary's refusal to believe the testimony of 25 persons who had heard the animal's cries. ${ }^{59}$ Emotional appeals were made to the residents of Hampstead to watch their pets, and handbills and notices against "Hampstead's Torture House" were widely distributed in the neighbourhood. Letters in local, and some national, papers maintained the attack, and Mrs Webber claimed in the Hampstead Advertiser that

... thousands of dogs all over England are being kept in similar Institutes in this cruel manner, pining and fretting their hearts out in lonely confinement for weeks and even months, before being tortured in the operation room. ${ }^{60}$

Public meetings were regularly held to arouse and sustain local indignation against the Institute, and the place had "secured a sinister reputation" according to the Abolitionist. In a paragraph that skilfully raised several fears, the article continued:

\footnotetext{
ss An almost identical campaign had been started in Chelsea at the end of the nineteenth century, when the Lister Institute for Preventive Medicine was planned, closely modelled on the Pasteur Institute. Co-ordinated by the Victoria Street Society, the campaign had raised the additional hazard of infection to the neighbours of the "great School of Cruelty", see CMAC/SA/LIS/E1-E7.

56 BUAV Annual report, 1921, pp. 12, 91.

57 The Institute had been registered in 1920, Home Office annual returns, 1921, vol. 20, p. 171.

58 The original petition, extensive correspondence between Dale, the Home Office and the MRC, and reports from Home Office Inspectors are included in NIMR/534ii 'Home Office 1920-23', and a detailed letter from Dale to Professor Thane, the Home Office Inspector for the NIMR, 8 Nov. 1921, is in 588/1, MRC Head Office and Sir Walter Fletcher, 1920-21', in the Archives of the National Institute for Medical Research, London, henceforward NIMR Archives.

${ }^{59}$ BUAV Annual report, 1922, p. 15.

6) The Hampstead Advertiser fostered a particularly virulent campaign, regular letters from members of the Hampstead branch of the BUAV appearing on its pages. Quote from Mrs Geraldine Webber's letter, 'Mount Vernon Medical Research Institute: facts about the poor dog there', Hampstead Advertiser, 19 Aug. 1920.
} 


\title{
E. M. Tansey
}

There is some resentment that while money is being poured out recklessly upon the vivisector's fads, the sick poor of Hampstead no longer have any place of refuge in sickness, since the Mount Vernon Hospital has changed its character from a place of healing for human beings to that of a place of disease-production for animals. We hear also, of the disappearance of pet animals, this may have no connection with Mount Vernon, but demand creates supply and we think a certain amount of nervousness is justified. $^{61}$

Confronted by local resistance, and the legal moves of another Dogs Protection Bill, the Medical Research Council began to consider alternative accommodation for animal breeding.

\section{MRC FIELD/FARM LABS}

As early as December 1918 the Secretary of the MRC, Walter Morley Fletcher, had recognized that the supply and maintenance of animals could become an acute problem. An internal memorandum circulated in January 1919 discussed whether the Committee's central institute should still be established at Hampstead, or whether advantage should be taken of the wartime disruption to site it elsewhere. Hampstead offered several advantages, including its convenient location for commuting staff, its internal construction, and the fact that it was already owned by the Committee. The major drawback that Fletcher envisaged was that of animal accommodation. Although the Hampstead site could provide holding facilities for small laboratory animals, it was impossible to keep larger animals there. In particular, he emphasized the special difficulties created by dogs in a residential area, as it was undesirable that their presence should be advertised "to either eye or ear". On a broader theme, Fletcher suggested that an ambitious breeding scheme of smaller animals might be enormously advantageous. He stressed

\begin{abstract}
Much immunological work is confused and hampered by the varieties of reaction found among different races of rabbits or guinea-pigs. Even relatively simple work like Salvarsan testing is hampered by differences of response in different samples of rabbits. The Committee would serve greatly by establishing 'pure' types of animals with standard reactions. Great financial economy might be effected also by some centralisation of the supply of animals for the study of nutrition. ${ }^{62}$
\end{abstract}

Fletcher recommended the establishment of an annexe, and suggested that a site near London might be developed relatively cheaply, re-using discarded huts and other temporary housing left at Hampstead by the wartime occupants. ${ }^{63}$ These arguments were

\footnotetext{
61 'Campaign at Hampstead', Abolitionist, 1920, 21: 140. Despite veiled allegations, there were no reports of pets being stolen for use in the Institute.

62 'Memorandum upon the Central Research Institute' dated 20 Dec. 1918, by Walter Morley Fletcher, MRC Report Book I, 1913-1928, pp. 172-8, MRC Archives.

${ }^{63}$ For similar reasons the Rockefeller Institute in New York acquired an animal farm at Clyde, New Jersey, in 1907, and was subject to similar claims of animal torture, pet stealing etc. that were levelled at the MRC, see G. W. Corner, A history of the Rockefeller Institute, 1901-1953: origins and growth, New York, Rockefeller Institute Press, 1964, pp. 83-7.
} 


\section{The Medical Research Council and anti-vivisectionist protest}

well received by the MRC and several different proposals and likely sites for such an extension were considered. ${ }^{64}$ One location in Mill Hill, to the north of London, was identified towards the end of 1920 by Henry Dale. ${ }^{65}$ He reported on its suitability to the MRC, emphasizing several important points: the provision of a regular supply of healthy animals was essential, an urgency increased by setting up and maintaining biological standards, ${ }^{66}$ and one that could not be guaranteed from external suppliers. "From outside sources the supply is inadequate, the price exorbitant and the quality bad". Dale argued that research was seriously compromised by the poor condition of animals and the prevalence of naturally acquired infections. Whilst the Hampstead accommodation permitted the maintenance of a small supply, the premises were not suitable to maintain an economical breeding programme. With regard to larger animals, Dale submitted,

Local sentiment, organised in advance of our arrival, has made the possibility of keeping a dog on the premises, even for a day or two, almost impossible; we can and do manage to accommodate an occasional goat or sheep in the grounds; but even one horse could not be healthily kept there, owing to the lack of room for exercise.

He felt there was every reason to accelerate the development of a facility elsewhere easily accessible to Hampstead. There, breeding programmes could be undertaken mindful of the prospective needs of the NIMR; and dogs could be kept without the annoyance of, or from, neighbours. Looking to the future, he also hinted, in line with Fletcher's thinking, that the MRC should consider producing a standard strain of guinea pig that could be supplied to all institutions engaged in biological assay. If they could do this, and produce animals free from infections, then he believed that they would be performing an invaluable service to British medical research. The cost of the 24 acre site at Mill Hill was $£ 6,000$, but Dale warned the MRC that land values were escalating as building pressure from London increased and speed was desirable. But, he cautioned, additional expenditure would be necessary to improve the site and construct new stables and animal houses, and estimated that a further $£ 5,000$ would be required in addition to the purchase price. ${ }^{67}$ After debating these recommendations, the MRC decided to proceed with the project, and although their bid for Frith Grange was unsuccessful, they purchased Rhodes Farm in Mill Hill the following year, and began converting the site into field laboratories. ${ }^{68}$ These rapidly

\footnotetext{
${ }^{64}$ MRC meeting, 3 Jan. 1919, Minute 3, 'Breeding \& Standard-isation Establishment'. The urgent need for an annexe to the Central Institute was agreed. The Treasurer and Secretary were directed to make enquiries, either near the John Innes Horticultural Institute or elsewhere, MRC Minutes Book II, 1915-1926, MRC Archives.

${ }^{65}$ Henry Dale to Walter Morley Fletcher, 25 Oct. and 1 Nov. 1920, NIMR/588/1, 'MRC Head Office and Sir W. Fletcher, I, 1920-22', NIMR Archives.

${ }^{66}$ Setting up and maintaining biological standards was a major responsibility of the MRC, see Thomson, op. cit., note 19 above, especially ch. 12, 'Biological standards', vol. 2, pp. 244-54.

67 'Proposed animal farm at Mill Hill', memorandum dated 13 Nov. 1920, by Henry Dale, MRC Report Book I, 1913-1928, p. 322, MRC Archives.

${ }^{68}$ MRC meeting, 10 Dec. 1920, Minute 182, 'Animal farm', the estimated expenditure, a substantial proportion of their annual income for that year, emphasizes the significance that the Council attached to the promotion of animal-based research. When Rhodes Farm was purchased, part of the site was immediately rented out to the Imperial Cancer Research Fund, meetings, 9 June 1921, Minute 297; and 21 July 1921, Minute 316; MRC Minutes Book II, 1915-1926, MRC Archives.
} 


\section{E. M. Tansey}

provided breeding and holding facilities for many species, which were then used in the Hampstead laboratories and elsewhere. In 1923 the provisions were greatly enhanced when the Field, a country magazine, raised funds through an appeal to support research already proposed by the MRC into canine distemper. ${ }^{69}$

Distemper, an acute infectious disease of carnivorous animals, was particularly common in puppies, and accounted for a high canine mortality. In late 1922 the editor of the Field, Sir Theodore Cook, contacted Sir Walter Morley Fletcher to discuss the possibility of supporting research work into the disease through an appeal to the magazine's patrons and readers. ${ }^{70}$ Such a proposal coincided with the MRC's scientific interests in investigating the group of diseases thought to be caused by "filterable viruses". ${ }^{71}$ The Council had already decided to support a major research programme at the National Institute on viruses, and Dale had started to search for a veterinary pathologist to develop distemper research. ${ }^{72}$ The Field was primarily motivated by concern for sporting dogs, but invited all dog-lovers and all dog-owners, estimated to be 3 million, to support the scheme. Their publicity stressed that

... by the centralizing of effort over so large an area, by the avoidance of overlapping, by the co-operation of the medical and veterinary professions ... we may justifiably hope for greater progress than has ever been made before. ${ }^{73}$

Although the magazine was at pains to emphasize the primary focus of their research,

We are informed that any advance in our knowledge of the causes of distemper will probably involve a similar advance in our power of controlling certain similar diseases in

\footnotetext{
${ }^{69}$ See Annual report of the MRC for 1922, and comment in the medical press, e.g., Br. med. J., 1923, i: 249.

70 An account of Cook's interest in distemper is given in A. A. Comerford, 'Two years field experience with the preventative treatment of distemper as advocated by Laidlaw and Dunkin' (Vet. Rec., 2.12.29), reprinted Birmingham, Hudson \& Son, c. 1930, NIMR Pamphlet Collection PI33. In it (pp. 22-3), F. T. G. Hobday, the Principal of the Royal Veterinary College, recounts an evening discussion with Dr Hammond Smith, one of the Field's sub-editors, "about the problems of distemper". Smith suggested instituting proper research and that the Field might be able to help. Hobday made an appointment to see Cook the following day, from which developed the Distemper appeal. See also the file of correspondence, 'Approach of Sir Theodore Cook to MRC', FD1/1274, in MRC Archives.

${ }^{71}$ A lengthy letter from Fletcher accepting the Field's collaboration in principle, details the conditions that should be agreed between the two bodies. It also emphasizes the prior concern of the MRC with this area of research. Fletcher to Cook, 14 Nov. 1922, 'Approach of Sir Theodore Cook to MRC', FD1/1274, MRC Archives.

72 Correspondence in 1922 between Dale and J. B. Buxton, his former colleague at the Wellcome Physiological Research Laboratories, indicates that plans for distemper work were well in hand. Buxton accepted a temporary position at Mill Hill at the beginning of 1923, but at the end of that year moved to Cambridge as Professor of Animal Pathology. He recommended George Dunkin, his brother-in-law, as his successor, letters in NIMR 439/1, 'Professor J. B. Buxton', NIMR Archives. For details of the Field/MRC collaboration see MRC Annual report, 1922-23, pp. 85-6; ibid., 1923-24, pp. 93-4; and for an account of the MRC's policy decisions on virology, see Thomson, op. cit., note 19 above, vol. 1, pp. 114-18.

${ }^{7.3}$ The appeal committee promised to keep the public fully informed of progress, and their regular reports, often amplified by press comment, kept the campaign in the public eye. For example, the first year of activity was well covered by The Times (25 June 1924), and the Daily Telegraph (27 Aug. 1924), the latter illustrated with photographs from a booklet produced by the Field Committee.
} 


\section{The Medical Research Council and anti-vivisectionist protest}

man. We welcome that possibility. But our first anxiety is to relieve the enormous amount of suffering and death in man's best friend, the dog. ${ }^{74}$

This appeal for funds to promote animal experimentation into an animal disease was greeted with considerable scorn by anti-vivisectionists, who derided the "fatuous" scheme, and ridiculed the MRC as particularly untrustworthy with animals. ${ }^{75}$ The Abolitionist singled out one particular appeal letter used by the Field, written as if from two dogs. This, they claimed, reached the lowest levels of maudlin sentimentality, which was characteristic of the Field's whole miserable entreaty. Conveniently, they disregarded their own contemporary posters in which a dog apparently pleaded "Don't vivisect me". 76 A bitter correspondence ensued between Miss Beatrice Kidd, the secretary of the British Union for the Abolition of Vivisection, and Sir Theodore Cook, the latter engaging reluctantly with a body he considered guilty of cruel mis-statements. He wrote

[I am] astonished to think from your letter that you appear to prefer that thousands of dogs should suffer from diseases that are preventable, rather than that every effort should be made to save them from their pain. ${ }^{77}$

He emphasized the Field Council's view that the investigations could not be conducted without experiments involving naturally infected animals, which might lead to the isolation of the causative organism, which might in turn provide the possibility of prophylactic serum or vaccine production. Sir Theodore's stance, the distemper appeal, and a concurrent petition for money for cancer research, were roundly denounced as "scare" campaigns by the anti-vivisectionist press.

But the distemper appeal did touch people's hearts and also their wallets. The original appeal suggested a range of contributions: from $£ 25$ per annum for three years for the Masters of famous packs of hounds (regarded as more important than the Privy Councillors by Cook), to two guineas for members of the public. Inspired perhaps by an early donation from the Prince of Wales, the published lists of contributions show that many small offerings were sent. In the first year over $£ 9,500$ was raised. ${ }^{78}$ The strategy attracted attention overseas, especially within the British Empire, and also from the United States, where a similar campaign was launched. ${ }^{79}$

An immediate strategy was to establish two complementary committees: the Field Distemper Council co-ordinated fund raising and publicized the campaign, whilst the

\footnotetext{
${ }^{74}$ From the first draft announcement, accompanying a letter from Cook to Fletcher, 25 Oct. 1922, in 'Approach of Sir Theodore Cook to MRC', FD1/1274, MRC Archives. Virtually unchanged, the notice appeared in most of the national newspapers in Feb. 1923. Privately, the Field was criticized by some readers because the proposal and the association with the MRC were too medical and scientific and thus too remote from the experiences of the general veterinary practitioner. See correspondence c., March 1923, in 'Approach of Sir Theodore Cook to MRC', FD1/1274, MRC Archives.

75 Abolitionist, 1923, 24: 41-2.

76 Ibid.

${ }^{77}$ Abolitionist, 1923, 24: 164-5.

7x 'The prevention of distemper: proposed research', letter from Lord Beaufort, Lord Portland and Sir Theodore Cook, The Times, 1 Feb. 1923, and 'Distemper in dogs', editorial, ibid. The appeal was published in most of the major newspapers, and usually attracted editorial support.

74) Cook to Charles H. Tyler about establishing an American Field Council, 6 March 1923, Approach of Sir Theodore Cook to MRC', FD1/1274, MRC Archives. The American Fund provided substantial support to the
} 


\section{E. M. Tansey}

Distemper Research Committee supervised the research work. Some clinicians refused to join the Distemper Committee, perhaps because of the association with a newspaper. This certainly seems to be the reason why the physician Humphrey Rolleston declined, until reassured by Fletcher that the MRC was acting as guarantor that the money raised would be expended on bona fide research. ${ }^{80}$ Fletcher failed however to persuade the surgeon Sir John Bland-Sutton, despite an impassioned plea that he could speak to both the professional and lay supporters of the scheme.

Laymen have to be educated in the meaning and value of research work. They are apt to think you can get results by putting "a penny in the slot" and they have to be taught that sometimes the longest apparent road is really the shortest cut.

Fletcher's appeal to Bland-Sutton reveals further that he recognized the political role that the distemper research work might play, and the motivations of many of the supporters of the 1919 Dogs Protection Bill.

You may remember that it was (and still is) chiefly the Tory squires, fox-hunters and other sportsmen in the House of Commons, who joined with the cranks and half the Labour men in supporting the Dogs' Bill. They do not mind animal experiments, but they think of their own retrievers or foxhounds and want them to be exempted from what they are told by the professional liars is 'torture'. I believe this dogs' distemper work may help to educate many of that class to realise how absurd the idea of torture is, and how much dogs and other animals have themselves to gain by animal experiment and improved knowledge. ${ }^{81}$

Despite this, Bland-Sutton still refused, for reasons not elaborated, to join the Distemper Committee.

The fund enabled specialized staff to be employed, and dedicated facilities to be built and developed at the Mill Hill site to study the disease. ${ }^{82}$ The first stipulation was to establish, by breeding in strictly isolated conditions, a stock of susceptible dogs, ones that had not acquired immunity to the disease. Distemper infection was so rife that it was only by supervised breeding in stringent quarantine conditions that this requirement could be met. Thus the Field initially provided new buildings and substantial fencing to create a completely isolated compound, with just one port of entry through a half-way house, where attendants and authorized visitors had to bathe and change into sterilized clothes.

There was some delay in constructing and altering these buildings, and hiring the staff who would live in the compound. By the middle of June 1924, the building work and

British Fund, e.g., they had donated $£ 3,400$ by the end of 1925 , from Field Distemper Fund report for 1927, in FD1/1285, MRC Archives.

${ }^{80}$ Fletcher to Rolleston, 12 Dec. 1922; Rolleston to Fletcher, 13 Dec. 1922, in 'Approach of Sir Theodore Cook to MRC', FD1/1274, MRC Archives.

${ }^{81}$ Fletcher to Bland-Sutton, 23 Jan. 1923; Bland-Sutton to Fletcher, 26 Jan. 1923, in 'Approach of Sir Theodore Cook to MRC', FD1/1274, MRC Archives.

${ }^{82}$ Detailed research plans were drawn up by Dunkin and Buxton, 10 April 1924, NIMR/472, 'Major Dunkin 1923-30'. One consequence of this support was Fletcher's insistence that the Mill Hill establishment be called the Farm Laboratories, and not Field Laboratories as originally intended, so as not to imply that the whole site was associated with the Field, Fletcher to Dale, 4 Nov. 1925, NIMR 588/4, 'MRC and Farm Labs 1925-37'. Correspondence in file NIMR 588/4g, 'Dog Compound, November 1939 to February 1940', includes several references to the earlier buildings and the financial arrangements with the Field fund, all in NIMR Archives. 


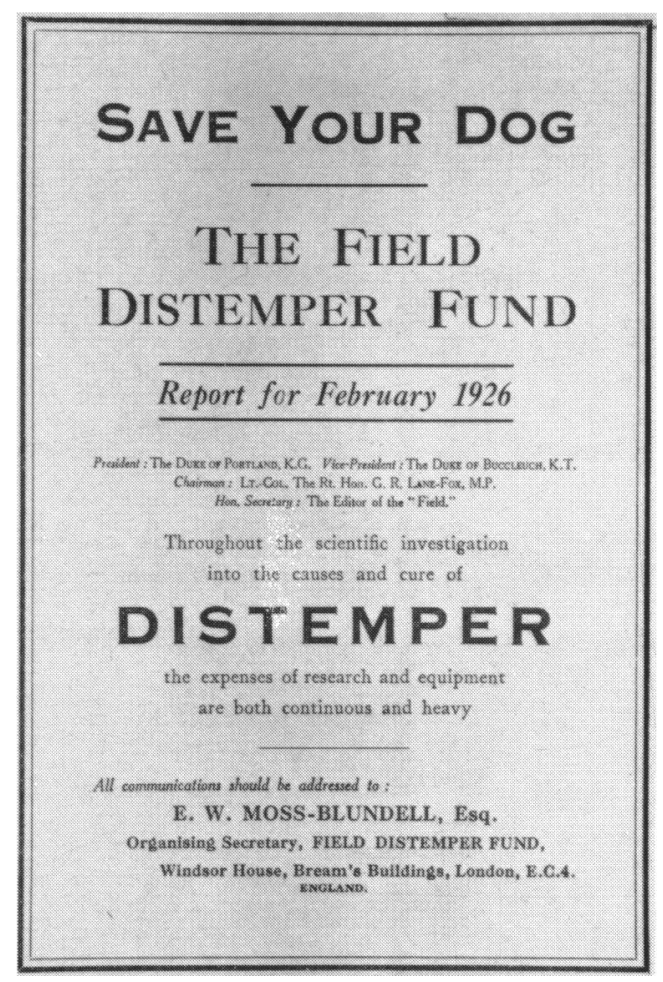

Plate 1: Front cover of Save your dog: the Field Distemper Fund, the annual report for 1926.

The Wellcome Institute Library, London

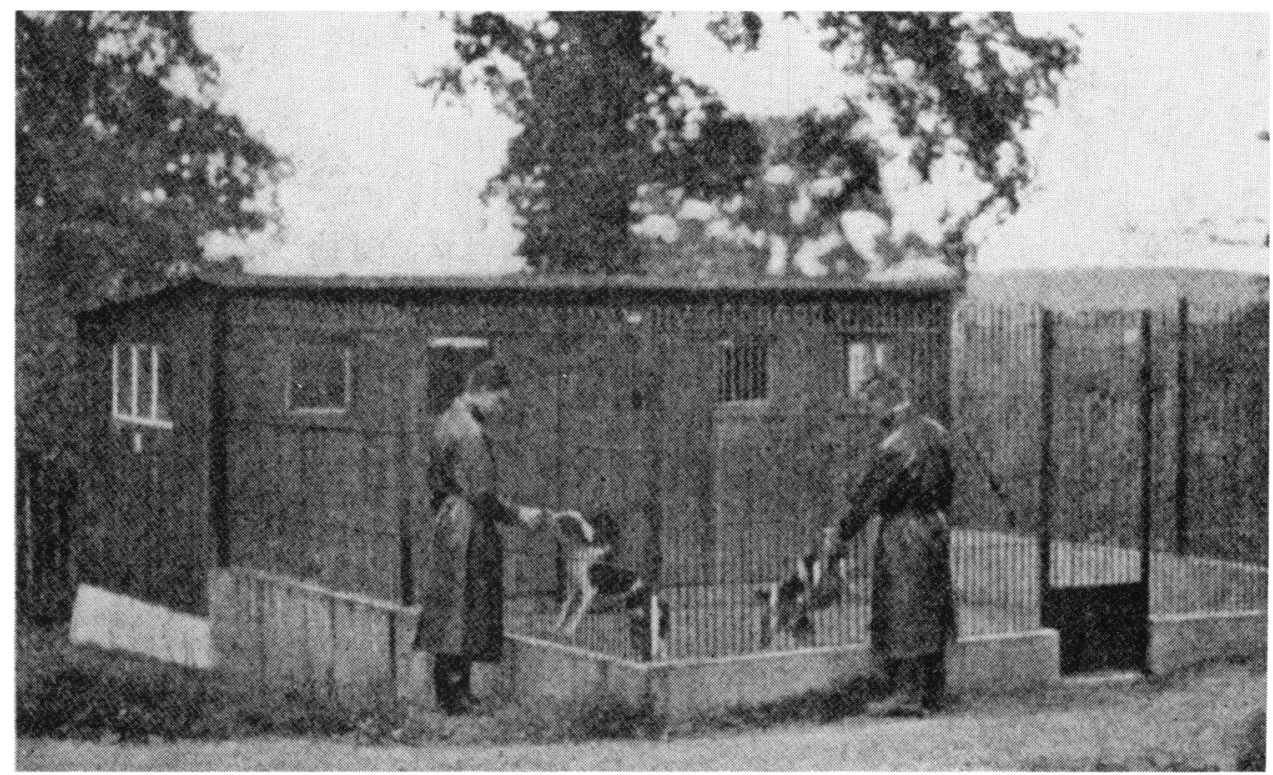

The Wellcome Institute Library. London

Plate 2: An isolation ward and outside run for dogs and puppies, Mill Hill, from A. Eichhorn, The research on canine distemper at Mill Hill, see note 118. 


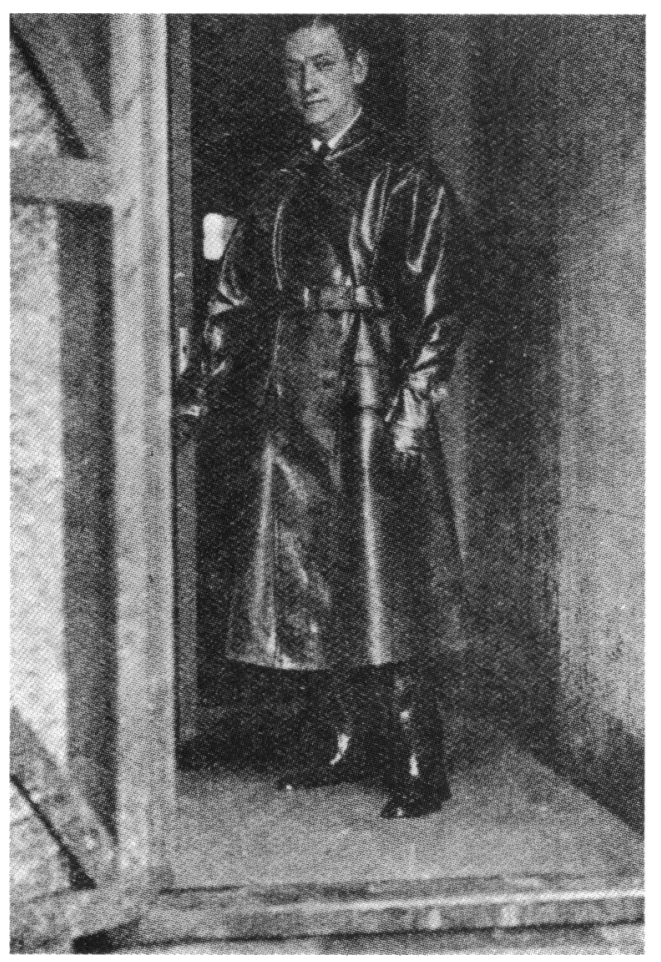

Plate 3: Entrance to the dog hospital, with attendant dressed in rubber clothing, standing beside a fly-proof door and behind a trough of disinfectant, from Save your dog: the Field Distemper Fund, the annual report for 1926 , p. 8.

The Wellcome Institute Library, London

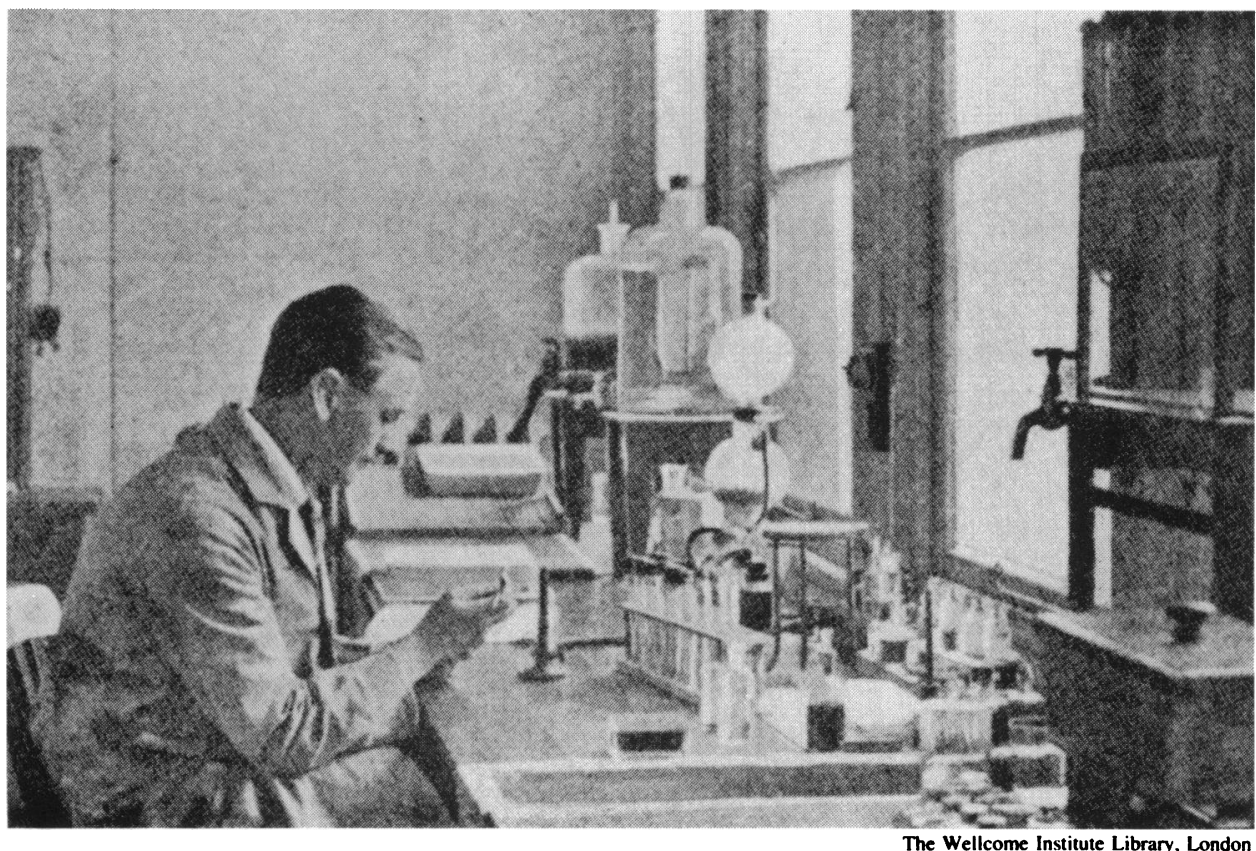

Plate 4: The laboratory at Mill Hill where much of the Field's research work was carried out, from A. Eichhorn, The research on canine distemper at Mill Hill, see note 118. 


\section{The Medical Research Council and anti-vivisectionist protest}

quarantine arrangements were completed, local girls trained in animal husbandry and isolation nursing techniques moved into the compound as the resident kennel maids, and the first bitches and puppies were transferred into the compound. ${ }^{83}$ Similar facilities were built to breed and then experimentally infect ferrets, because the NIMR's veterinary pathologist was familiar with gamekeepers' experience that ferrets were also susceptible to distemper.

\section{THE ISOLATION COMPOUND AND THE RESEARCH WORK ${ }^{84}$}

After exposure to a diseased dog, each newly infected puppy was placed in an individual cubicle, as were clean, uninfected puppies which were maintained in identical conditions as controls. A strict cleaning schedule for each dog's cubicle and for the disinfecting of the attendants, feeding tins, and sample tubes was devised. Under conditions of stringent isolation, samples of infected blood and other materials were passed through the compound barrier, and the progress of both ill and healthy dogs was studied. The varied skills of the scientific staff of the NIMR were brought into the investigation, and bacteriological, pathological, and histological expertise all contributed to the project. Their joint efforts rapidly confirmed earlier suggestions that the infective agent was a virus and that bacterial infections were secondary invaders responsible for complications. The distemper work, although independently funded and directed to a large extent, was fully integrated with the other research activities of the NIMR's staff. For example, concurrent work on cancer-causing viruses was being undertaken by Gye and Barnard in the Hampstead and Mill Hill laboratories using similar techniques and resources, and announcements from the MRC about the progress of their investigations drew forth an appreciative comment from the Field, as the association between the two projects was recognized. ${ }^{85}$ The MRC's Annual report for 1925, which summarized the first results in both the cancer and distemper work, reported that dogs could indeed transmit the distemper infection to ferrets, an immensely significant finding as a smaller, cheaper animal model for the disease thus became available. ${ }^{86}$ Not surprisingly perhaps, the Abolitionist reported that the experiments were futile, would continue to be so, and no benefit would accrue. ${ }^{87}$

\section{DOGS PROTECTION BILLS AND THE DISTEMPER RESEARCH}

Whilst the MRC's distemper labs were being established, attenupts continued to restrict

${ }^{x}$ Just five months later the compound was already overstocked with pregnant bitches and puppies, and Dunkin suggested to the MRC that a further building would be necessary, Dunkin to Dale, 17 Nov. 1924 , NIMR/472, 'Major Dunkin 1923-30', NIMR Archives.

${ }^{x+}$ Brief accounts of the canine distemper work at NIMR are given by Thomson, op. cit., note 19 above, vol. 2, pp. 119-22; Austoker and Bryder, op. cit., note 19 above, pp. 40-1.

${ }^{85}$ W. E. Gye, 'The aetiology of malignant new growths', Lancet, 1925, ii: 109-17; J. E. Barnard, 'The microscopical examination of filterable viruses associated with malignant new growths', Lancet, 1925, ii: $117-23$.

${ }^{86}$ Dale to Fletcher, 19 Nov. 1924, NIMR 588/1, 'Sir Walter Morley Fletcher, 1923-24', NIMR Archives; MRC Annual report, 1925, pp. 102-3, see also, P. P. Laidlaw and G. W. Dunkin, 'Studies in dog distemper I. Dog distemper in the ferret', J. comp. Path. Ther., 1926, 39: 201-12; idem, 'Studies in dog distemper II. Experimental distemper in the dog', ibid., pp. 213-21; idem, 'Studies in dog distemper III. The nature of the virus', ibid., pp. 222-30.

${ }^{87}$ Abolitionist, 1925, 26: 16. 
the use of dogs in experiments. ${ }^{88}$ In 1923 Sir Frederick Banbury MP unsuccessfully introduced a Dogs Protection Bill into the House of Commons; the following year, newly ennobled, Lord Banbury re-introduced his Bill into the House of Lords. During the subsequent debate, the Lord Chancellor stressed the Government's view that such a Bill would end the essential research undertaken by the MRC. An element of farce was introduced when Lord Knutsford, who was also the chairman of the Research Defence Society, advanced the MRC's canine distemper research as a justification for using dogs in experiments. At this, Lord Lambourne suggested that work on distemper should be excluded from the Bill exempting dogs from experiments. Although there was a little support, many of their Lordships spoke against the proposal, and Lord Mildmay, a member of the MRC, objected forcefully that it would make the Council's work on distemper illegal. After a full debate, the second reading of the Bill was rejected without a division. $^{89}$

In 1925 Lord Banbury re-introduced yet another Dogs Protection Bill into the House of Lords. Lord Knutsford once more advanced the utility of the research in canine distemper, and suggested that if this Bill was to be brought in year after year, with the same stereotyped arguments for and against, it would be more comfortable if a gramophone recording could be made, to be listened to in the calm of the tea room. ${ }^{90}$ The Bill was defeated by 77 votes to 8 . The Abolitionist noted that "his Lordship conveniently ignores the fact that these experiments have so far drawn a blank, and can confidently be expected to continue to do so," although it conceded that Lord Banbury was particularly ineffectual in debate. ${ }^{91}$ Despite the victory, Lord Knutsford cautioned the BMA's Science Committee:

You must get ready again for him [Banbury] and I suggest that the BMA should pass a resolution setting out what the profession does owe to experiments on dogs. I take it that most of Lewis' work on Heart was done on dogs-insulin of course-and somebody else's on blood pressure and digestion. We need another statement from a body like yours that dogs are necessary. I have used of course your former Resolution, but it needs to be more recent and a revised version strengthened by new researches would be valuable. ${ }^{92}$

\section{7: A CHANGED CLIMATE}

In 1927, three related events occurred which highlight the main themes of this paper. Firstly, anti-vivisectionist groups, fuelled by a successful legal case involving stolen dogs,

\footnotetext{
${ }^{8 x}$ A brief anti-vivisectionist account of the progress of Dogs Protection Bills during the 1920s is provided by E. Westacott, A century of vivisection and anti-vivisection, Ashington, C. W. Daniel, 1949, especially, 'Dogs and vivisection', pp. 530-7.

${ }^{89}$ Parliamentary reports on the Dogs Protection Bill, The Times, 26 March 1924, Daily Telegraph, 26 March 1924, BUAV Annual report, 1924, pp. 13-18. During the same period, attempts had also been made to introduce into the House of Commons a Bill to prevent public funds financing experiments on animals, but both in 1923 and in 1925 these were unsuccessful.

${ }^{90}$ Reported in an editorial summarizing the many Parliamentary efforts that had been made to exempt dogs from experiments, Fight against Disease, 1937, CMAC/SA/RDS/G1/49.

${ }_{91}$ Abolitionist, 1925, 26: 63. As the organ of the Society advocating total abolition of animal experiments, the paper was unable to support a Bill exempting only dogs from experiments. Ironically, after Lord Knutsford's comments about a gramophone recording, the Secretary of the British Union for the Abolition of Vivisection, Dr Hadwen, made a record to be played at local meetings he was unable to attend. BUAV Annual report, 1929, p. 12.

${ }^{92}$ Minutes of BMA Science Committee, 8 May 1925, CMAC/SA/BMA/C.87, 'Vivisection: Dogs Protection Bills: minutes and cuttings 1908-1949'. However, it w'as not until the introduction of a further Bill that the
} 
promoted a new Dogs Protection Bill that was presented in a substantially different context from previous Bills; secondly, the advocates of animal experimentation countered this move in a more determined and coherent manner than previously; and finally, the Field, on the basis of reported success with the distemper work, launched an appeal for further funds.

In November 1926 there had been a highly publicized successful prosecution of a dog dealer who had supplied two stolen dogs to the Institute of Physiology of University College London. ${ }^{93}$ This, the first such case, excited considerable interest, and questions were immediately raised in the House of Commons, although the Home Secretary declined to contemplate further action. ${ }^{94}$ Finally, anti-vivisectionist groups had damning evidence of the pet-stealing they had warned against for many years. An orchestrated campaign against animal experimentation was launched, and renewed efforts were made to bring a Dogs Protection Act onto the statute books. At the beginning of 1927, letters appeared in several leading newspapers asking dog-lovers to sign a petition to exempt dogs from vivisection. Co-ordinated by the National Canine Defence League this became the basis of a fresh Dogs Protection Bill. ${ }^{95}$ The petition claimed that dogs were used "for demonstrations of a prolonged and agonising nature", which prompted a medical MP to seek verification and explanation of such allegations. The Under-Secretary of State at the Home Office denied the accusations and hoped his answer would get wide circulation. ${ }^{96}$ That hope was misplaced. What did get wide circulation were allegations of cruelty and suffering. The BUAV produced an emotional pamphlet called Watch your pets exhorting people to protect their dogs, as strays were always wanted by vivisectors. ${ }^{97}$ Quoting selectively from the official Home Office statistics, they claimed that over 200,000 animals had been operated on, the vast majority without anaesthetics. The sensational phrase "they boil dogs alive" appeared. And in a smart tactical move the London and Provincial Anti-vivisection Society advertised the petition on the back of entry forms for Cruft's Dog Show, thus reaching a guaranteed audience of dog-lovers. ${ }^{98}$ The Royal

Committee produced a draft article, which was amended and approved at their meeting of 2 July 1926 and published under the title of 'The need for the use of dogs in physiological and therapeutic experiments', $B r$. med J., 1926, ii: $1073-4$.

${ }^{9.3}$ Details are in $B r$. med J., 1926, ii: 1028. The dealer, Hewett, signed a declaration that his animals had been legally obtained. Nevertheless, the Professor of Physiology at UCL, Lovatt Evans, acknowledged that the anomalous position with regard to the supply of laboratory animals left laboratories vulnerable to such deception. The case provoked a flurry of publicity in the national and medical press, see, e.g., "Experiments on animals". Lancet, 1926, ii: 1174-5, and Lovatt Evans to the Research Defence Society, 1926, CMAC/SA/RDS/C2 Minutes Book, 1920-1948. A comparable situation in America is discussed in Lederer, op. cit., note 3 above, passim.

")+ 'Dogs for research', $B r$. med J., ii: $1085,1202$.

"s The chairman of the National Canine Defence League was Sir Robert Gower MP, who introduced the Bill into the House. For the League's AGM and other anti-vivisectionist society meetings that year, see 'Anti-vivisection meetings", Br. med J., i: 1153.

"Dr Freemantle, later Sir Francis Freemantle, was then the chairman of the Parliamentary Medical Committee. Br. med J., 1927, i: 549; see 'Medical notes in Parliament: experiments on animals", Br. med. J., i: 497.

${ }^{17}$ A public petition presented to the Home Secretary suggested that the police should be allowed to empower individuals who had lost pets to inspect kennels and animal houses attached to registered premises. The Home Secretary, admitting no authority in the matter, "said that the idea... was a good one", Medical notes in Parliament', Br. med. J., 1927, i: 359.

${ }^{9 x}$ Again (see note 91 above), the BUAV could not of ficially condone a Bill arguing for only partial abolition of vivisection, Abolitionist, 1927, 28: 43. The RDS attempted to counter these claims in their publicity material and in their journal Fight against Disease. The issue for Oct. 1927 contains lengthy refutations of the BUAV's pamphlet, CMAC/SA/RDS/J1/16(a). 


\section{E. M. Tansey}

Society for the Prevention of Cruelty to Animals also added their support to the League's petition, although it was soon withdrawn. ${ }^{99}$

The public furore that had accompanied the stolen dog case, and the associated anxieties that had been raised and maintained by the emotional literature and meetings, meant that the medical and scientific professions were under considerable threat. ${ }^{100}$ Very quickly the Canine Defence League collected one million signatures. ${ }^{101}$ This time there was a very real fear that a Bill might succeed, and the proponents of animal experimentation united in recognition of a much more serious fight on their hands. ${ }^{102}$

The earliest concerns were expressed by the Physiological Society and the Editor of the Field, Sir Theodore Cook. The Committee of the Physiological Society submitted a memorandum to the MRC in January 1927, drawing attention to the increasing difficulty of obtaining dogs, and to a lesser degree cats, and the problems that laboratories faced of unwittingly purchasing stolen animals. They urged the MRC to seek an amendment of the law forbidding the use of unclaimed stray animals. ${ }^{103}$ The MRC agreed that whilst such an amendment was desirable, it was unlikely to be practicable. They reported that their own experiences of providing dogs by special breeding was, in normal circumstances, impractical because of the cost. ${ }^{104}$

In the same month, Sir Theodore Cook also wrote to the MRC, the Research Defence Society, and various unidentified members of the Government, to express his worry that restrictions on dog experiments would seriously impede the Field's canine distemper research. He suggested to the Chairman of the Research Defence Society that all the interested bodies should formulate a plan of campaign, and make every effort to ensure that their efforts did not overlap. He maintained, "I shall be glad therefore if we can keep in touch throughout . . . as you can hit out where I must be silent and I can pole-axe where you have to be careful." 105

Cook's public "pole-axing" included correspondence in The Times and articles in the Field contrasting the scourge of distemper with the progress being made at the Mill Hill labs of the MRC.

The British Medical Association strategy involved not only opposition to the Bill, but also a simultaneous attempt to secure better conditions for the supply of experimental

\footnotetext{
"99 This move was met with some disgust by the medical press, see, e.g., 'The experimental method in the healing art', Br. med. J., i: 390; 'RSPCA', ibid., p. 394; and shortly afterwards it was announced that the Society had withdrawn its support, 'RSPCA', ibid., p. 440.

${ }^{10()}$ In the wake of the UCL incident, the Science Committee of the BMA produced a memo supporting the use of dogs, for the benefit of members who "may have present occasion to consider the subject and possibly advise members of the lay public upon it". "The need for the use of dogs in physiological and therapeutic experiments", Br. med. J., 1926, ii: 1073-4.

(0) 'Methods and menace of anti-vivisection', Fight against Disease, April 1927, CMAC/SA/RDS/J1/15(a).

102 MRC meeting, 28 Jan. 1927, Minute 4, 'Experiments on dogs'. A memorandum expressing the views of the MRC was to be circulated in draft, and then submitted to the Lord President, MRC Minutes Book III, 1927-1936, MRC Archives.

10.3 Initiated by Sir Edward Sharpey-Schafer at a Committee meeting in Dec. 1926, the Physiological Society prepared a memorandum, which was presented to the MRC by Sir Joseph Barcroft and A. V. Hill. The Physiological Society Committee Minutes 1912-1933, CMAC/SA/PHY/B1/2.

${ }^{104}$ MRC meeting, 28 Jan. 1927, Minute 4, 'Experiments on dogs', MRC Minutes Book III, 1927-1936, MRC Archives.

I115 Sir Theodore Cook to Lord Knutsford, 18 Jan. 1927, CMAC/SA/RDS/J1/29. Following Cook's lead, the RDS also maintained a press campaign, see CMAC/SA/RDS/J1/33.
} 
animals. Their principal objective was to achieve a repeal of the section of the 1906 Dogs Act which prohibited police from handing over unclaimed strays. ${ }^{106}$ They issued an invitation to interested parties, including the MRC, the Research Defence Society, and the Physiological Society, to join together to counteract the "venomous attitude" of the Canine Defence League. ${ }^{107}$ The "Conference of Representatives of Medical and Scientific Bodies on Research and Animal Experimentation" met at BMA House on 4 April 1927. ${ }^{108}$ More than fifty organizations were represented at the Conference, the minutes of which formed the basis of a supplement to the $B M J .^{109}$

The Royal Society of Medicine, prompted by the Research Defence Society, added their support, "[feeling] bound to place on record their earnest hope" that the Bill would not become law as it would force able research workers abroad, to the detriment of British medicine. ${ }^{110}$

The MRC produced in 1927, as they had done in 1919, a detailed memorandum listing the benefits that had accrued from research on dogs. This concentrated almost exclusively on work on disease of human significance, and the distemper research was mentioned in only one sentence in the seven-page report, "[T]he experimental study of distemper in dogs has recently given new knowledge and new methods by which the protection of dogs from this heavy plague is already becoming practicable." They emphasized their duty to apply Government monies for the promotion of medical research, and in their "unanimous and considered judgement that Dogs' Protection Bill would place an insuperable and permanent barrier across some of the chief paths of progress in this work". 11

The memorandum addressed directly the fears of pet-stealing, recognizing the difficulties of a laboratory innocently purchasing stolen animals, however stringent their precautions. Turning the problem around, they too sought a repeal of the Dogs Act (1906) Section 3(5), to allow strays to be used for experimentation.

About 50,000 dogs are said to be destroyed annually in London alone under these provisions: they are destroyed uselessly.... [If repealed] the police would ... transfer stray and unsaleable dogs remaining unclaimed by any owner to a suitable authority

\footnotetext{
${ }^{106}$ MRC meeting, 29 April 1927, Minute 55, 'Dogs'; a draft statement was circulated based on the memorandum submitted in 1919 to the chairman of the National Health Insurance Joint Committee by the then Medical Research Committee on 2 May 1919, which was subsequently submitted to Parliament (Cmnd 161). After some discussion, the draft was approved and sent to the Lord President of Privy Council. The MRC also considered practicable steps to repeal subsection (5) of the Dogs Act of 1906 which prohibited police from handing over unclaimed strays. MRC Minutes Book III, 1927-1936, MRC Archives.

${ }^{107}$ Secretary of the BMA, Dr Arthur Cox to Crowden, Secretary of the RDS, 11 March 1927, CMAC/SA/RDS/ J1/35. 'The defence of research: the conference on animal experimentation', Brit. med. J., 1927, i: 637. MRC meeting, 18 March 1927, Minute 22, 'Expts on dogs'. A meeting of representatives of medical bodies was convened for 4 April 1927 by the BMA to express the opposition of the medical profession to the Dogs Protection Bill before Parliament, and to secure better conditions for the supply of animals for experiments. Walter Morley Fletcher was designated to represent the MRC, MRC Minutes Book III, 1927-1936, MRC Archives.

${ }^{108}$ Organizations such as the Medical Research Council, the National Institute for Medical Research, the Physiological Society, the Pharmaceutical Society, and the Field Distemper Council, and most universities and medical schools sent representatives.

${ }^{109}$ Minutes of the Conference in CMAC/SA/BMA/C87, and further copies of publications and newspaper cuttings are in CMAC/SA/BMA/C88.

110 W. Girling Ball, Secretary of the RSM, wrote to Lord Knutsford emphasizing that the RSM was well aware of the grave issues involved, CMAC/SA/RDS/J1/2j.

111 Medical Research Council, Memorandum upon the Dogs Protection Bill [Cmnd 2880], London, HMSO, May 1927, quotes on pp. 6 and 1 respectively.
} 


\section{E. M. Tansey}

approved by the Home Office for the purposes of experimentation under the existing law and Home Office regulations. This would remove or make negligible the dangers to which attention has been drawn. It would not involve any risk of valued pet dogs being used for experiment. ${ }^{112}$

Thus, the British Medical Association, the Royal Society of Medicine, and the Medical Research Council all publicly proclaimed their opposition to the Bill on the basis of the medical benefit from experiments on dogs. What about the veterinary benefit? Prompted by the Research Defence Society, the Royal College of Veterinary Surgeons produced a statement on the necessity of using dogs, concentrating their account on diseases peculiar to dogs-distemper, canine typhus, mange, parasitic worms. ${ }^{113}$ They also requested every member of the veterinary profession to write to their MP expressing opposition to the Bill, and to emphasize the work on distemper in their correspondence. ${ }^{114}$ This support was particularly appreciated by the scientific community, as stressed in a letter from Henry Dale to the Director of the field labs at Mill Hill, "The most valuable reinforcement that the Veterinary profession can give is, to show that dogs themselves would be the worst sufferers if the Bill becomes law." 115

Throughout, the Research Defence Society co-ordinated the activities and publications of those opposing the Bill. One anti-vivisectionist sent their material, whether by design or accident is not clear, wrote angrily that the ploy of using dogs to save dogs was one of the most despicable pleas that he had ever encountered. ${ }^{116}$ This rage was consistently echoed in articles in the Abolitionist, and the fury was compounded when, later that year, the MRC Distemper Research Council announced that a vaccine had been prepared from a killed preparation of the virus, and was undergoing trials. ${ }^{17}$ The Government decided to oppose the Bill, and once more the Dogs Protection Bill was unsuccessful.

That first vaccination of ferrets and dogs was found not to provide reliable long-term protection. ${ }^{118}$ The Field launched another appeal to provide further funds for research and

\footnotetext{
112 Ibid., p. 8. See also, MRC meeting, 29 April 1927, Minute 55, 'Dogs', MRC Minutes Book III, 1927-1936, MRC Archives. The memorandum accorded entirely with the views of the BMA, Br. med. J., 1927, i: 1066.

11.3 The statement by the RCVS was subsequently published in the RDS's Fight against Disease in the summer of 1928, CMAC/SA/RDS/J1/A.

114 F. W. Bulloch, Secretary, RCVS, to Dr Crowden, RDS, 27 April 1927, CMAC/SA/RDS/J1/55.

115 Letter from Dale to Dunkin, 23 Feb. 1928. Dale suggested that the RCVS might also mention studies that would throw light on human disease, although that point had been emphasized by the MRC, NIMR/472, 'Major Dunkin 1923-30', NIMR Archives.

116 Sir Leo Chiozza Money to Secretary of the RDS, 19 April 1927, CMAC/SA/RDS/J1/62.

117 See MRC Annual report, 1926-27, pp. 100-1, and MRC Annual report, 1927-28, pp. 105-7. Laidlaw and Dunkin first successfully immunized ferrets in early 1926, but experienced great difficulty in reproducing the effect in dogs, see confidential progress report, 7 Oct. 1926, by Dr P. P. Laidlaw and Dr G. W. Dunkin to Field Distemper Council, FD1/1277, MRC Archives. See also, P. P. Laidlaw and G. W. Dunkin, 'Studies in dog distemper IV. The immunisation of ferrets against dog distemper', J. comp. Path. Ther., 1928, 41: 1-17, idem, 'Studies in dog distemper V. The immunisation of dogs', ibid., pp. 209-27. A killed virus preparation was used because it had not been possible, at that stage, to grow the virus outside the body. Most of the trials were undertaken on packs of fox-hounds, and over a thousand animals were successfully inoculated between 1927 and 1928. These preliminary results were taken up rapidly by the Wellcome Foundation in an attempt to produce a widely available commercial vaccine.

II8 Although the advances were of much interest to American investigators, and Dr Eichhorn, the Director of the Veterinary Department of Lederle Laboratories, the former chief of the Pathological Laboratories of the U.S. Bureau of Animal Industry, visited Mill Hill to see Laidlaw and Dunkin. Eichhorn represented the American Distemper Committee, which followed the British work closely, and reported that of 2,000 inoculated dogs, only
} 


\section{The Medical Research Council and anti-vivisectionist protest}

over the next few years technical developments produced more satisfactory prophylactics, providing better long-term protection with fewer side effects. ${ }^{19}$

From the middle of the 1920 s the MRC were able to protect some of their laboratory dogs, and towards the end of 1926 local owners requested vaccination for their pets. In that first year more than thirty dogs were sent to the Farm labs for treatment, and the practice continued for some years until commercial preparations became available. ${ }^{120}$ A survey in 1931 of the many hundreds of dogs immunized in this way provided valuable information on the efficacy of different preparations. ${ }^{121}$ The considerable publicity generated by these developments disgusted the Abolitionist, which bitterly denounced press gullibility in advocating the new therapy. It and other anti-vivisectionist journals were put in a difficult position by the success of a project that apparently improved the health and well-being of animals, and they desperately searched for critical reports of the vaccine. ${ }^{122}$

All through this period, attempts to bring in a Dogs Protection Act continued. ${ }^{123}$ In 1933, a Bill was introduced again, just as widespread publicity was given to a much improved distemper vaccine resulting from the work of the MRC. ${ }^{124}$ When the Home Secretary was asked in the House of Commons whether the work would have been possible if the Dogs Protection Bill had been passed, he replied that it would have been illegal. The Dogs Protection Bill was subsequently withdrawn.

By the mid 1930s the NIMR was firmly established in Hampstead and ritual objections to its presence were raised only occasionally in the anti-vivisectionist press. Visits by both professional and lay groups to the main Institute and to the Mill Hill laboratories, within the constraints of the quarantine regulations, were frequently allowed. ${ }^{125}$ The successful

seven had developed any disease symptoms, only two of which were diagnosed as distemper. For his report, see A. Eichhorn, The research on canine distemper at Mill Hill: a report to the Distemper Fund subscribers, issued by the American Distemper Committee, Boston, Mass., c. 1929.

${ }^{119}$ Abolitionist, 1927, 28: 10, concentrated its denunciation on the dangerous side effects.

120 The legal implications of the request, whether such inoculations could be offered as treatment by the Institute, or whether they came under the 1876 Cruelty to Animals Act as experiments, were discussed by the staff. See Home Office circular 26 Nov. 1926, and Dale to Dr Gibbs (the Home Office Inspector for the NIMR), 29 Nov. 1926, NIMR/534, 'Home Office iii, 1924-1928', NIMR Archives. An early request for vaccine came from one of the Field's most prominent supporters, the Duke of Portland. The MRC explained that it was impossible to comply, as vaccine was freshly made in the labs and in short supply. They did offer to take some of the Duke's pedigree hounds into the isolation compound at a later stage, and hoped they could use his dogs in properly controlled experiments. A. L. Thomson to Cook, 5 Nov. 1926, 'Field Distemper Council', FD1/1277, MRC Archives.

121 P. P. Laidlaw and G. W. Dunkin, 'Some further observations on dog distemper', Am. Vet. J., 1931, 78: $545-51$.

12 Reports focused on either deaths or unpleasant side effects resulting from the vaccine, e.g., Abolitionist, 1929, 30: pp. 16, 29, 75. The withdrawal of the occasiona! faulty batch of trial vaccine was greeted with glee, e.g., ibid., 1931, 32: 57 .

${ }^{12.3}$ Bills were introduced into the House of Commons on 13 Feb. and 14 Nov. 1928, 4 Nov. 1929, 29 Nov. 1932, 12 May and 6 Nov. 1936, and in 1937 a Bill was introduced applying to Scotland only, details in CMAC/SA/RDS/J12. Repeated efforts were also made to amend the 1906 Dogs Act, e.g., Br. med. J., 1928. ii: $132-3$.

${ }^{124}$ P. P. Laidlaw and G. W. Dunkin, 'Studies in dog distemper VI. Dog distemper antiserum', J. comp. Path. Ther., 1931, 44: 1-25.

125 One significant visit was that of the Parliamentary Medical Committee in late 1929. Other public relations activities included lecturing on the work to a wide variety of audiences. For example, Dale gave the 1931 Paget memorial lecture to the Research Defence Society, and Dunkin spoke to the Canterbury Rotary Club on 'Vivisection'. Dunkin also gave the University of London Advanced Lectures in Veterinary Science in Nov. 1929, on 'Recent researches on immunization against distemper in the dog'. Dale regarded such talks by Dunkin, 


\section{E. M. Tansey}

distemper research, and the considerable publicity and popular support that it received, played a significant part in establishing the credentials of the MRC and its research programmes with the general public, and in simultaneously discrediting anti-vivisectionist opposition. The MRC was expanding and looking for a site on which to build a new National Institute for Medical Research, as the Hampstead buildings were overcrowded and congested. ${ }^{126}$ Ironically perhaps, the land at Mill Hill was chosen, and the flagship laboratory of the MRC thus came to be built on the site of the original animal farm and distemper kennels. The animal breeding facilities remained and ferrets continued to be bred there. Having been successful as models for one viral infection they were extensively utilized in influenza research. ${ }^{127}$ All animals bred at the farms were also made available to other MRC workers, and as a profitable sideline, ferrets were supplied to sportsmen, the reputation of MRC animals, inoculated against distemper, being exceptionally high. ${ }^{128}$

Several important themes emerge from this account. One is the significance of state-supported medical research, exemplified by the creation of the MRC, which explicitly condoned, to an unprecedented degree, animal experimentation. The portent of this development was recognized immediately by the anti-vivisectionist organizations, who overcame internecine disagreements and disputes to co-ordinate several responses to the research provision of the National Insurance Act, including a major protest rally in Central London. ${ }^{129}$ The objections were intensified and focused on a conspicuous target when a dedicated research institute was proposed, and the conversion of a former hospital into that institute typified further a powerful and recurrent argument used by antivivisectionists, of human healing versus animal suffering. The situation of the building in a predominantly middle-class residential area provided a fertile environment for the stimulation of further protests at both local and national levels and a well-articulated campaign of letter writing to the press, regular neighbourhood protest meetings, and complaints to Members of Parliament characterized the protests in Hampstead. Similar campaigns had been initiated against the Brown Animal Sanatory Institute, created in south London in 1871, and against the Lister Institute on the Chelsea Embankment in 1894 , but both were situated in largely non-residential areas. That against the Brown was

a veterinary surgeon, as particularly valuable. Letters and correspondence in NIMR/472, 'Major Dunkin 1923-30', NIMR Archives.

${ }^{126}$ MRC meeting, 22 Jan. 1932, Minute 7, 'Farm Labs'; proposals for a new building for small animals were submitted. Plans and estimates were obtained, and later in the year, a new animal house was completed, MRC meeting, 21 Oct. 1932, Minute 152, 'Farm Labs'. The members of the MRC visited the labs to inspect the new building. All in MRC Minutes Book III, 1927-1936, MRC Archives.

${ }^{127}$ See, e.g., Wilson Smith, C. H. Andrewes and P. P. Laidlaw, 'A virus obtained from influenza patients', Lancet, 1933, ii: 66; Wilson Smith and C. H. Stuart-Harris, 'Influenza infection of man from the ferret', Lancet, 1936, 2: 121-3. A personal account of the early experiments is given in C. H. Andrewes, The common cold, London, Weidenfeld and Nicolson, 1965, pp 40-1.

${ }^{128}$ Letters A. L. Thomson to H. H. Dale, 3 Oct. 1932; H. H. Dale to A. L. Thomson, 4 Oct. 1932, in NIMR 588/4, 'MRC and Farm Labs 1925-1937', NIMR Archives. Problems of supply continued: in 1947 the Laboratory Animals Bureau was established at the NIMR, but soon moved to the Royal Veterinary College as an animal breeding enterprise, see P. H. O'Donoghue, 'The establishment of laboratory animal science in the United Kingdom', in The Laboratory Animal Association Silver Jubilee, ed. J. H. Seamer, London, Royal Society of Medicine Services for Laboratory Animals Ltd., 1988, pp. 2-8.

${ }^{129}$ State supported research has been a particular focus for anti-vivisectionist complaint, see, e.g., the regular denunciations of the MRC's annual reports by the Abolitionist; E. Westacott, 'The use of public funds for vivisection,' in Westacott, op. cit., note 88 above, pp. 562-9; and M. Beddow Bayly, The taxpayer and experiments on living animals, London, Animal Defence and Anti-Vivisection Society, 1938. 


\section{The Medical Research Council and anti-vivisectionist protest}

intermittent and never achieved a high degree of local involvement. ${ }^{130}$ Against the Lister Institute, then called the British Institute for Preventive Medicine, objections were more sustained, and a petition of protest signed by 1,000 Chelsea residents was presented to the Home Secretary in April 1894. The Institute's Council investigated the complaints and discovered that in one of the few blocks of flats in the area, the residents had formed "a sort of Trades Union to strike against it, i.e. to leave if the Institute was allowed". ${ }^{131}$ As with the later scheme of the MRC and the Field, prominent supporters were rallied, and in this instance the support of the Duke of Westminster, the landlord of most of the area, was important. He had sold the land on which the institute was to be built, and, as one resident observed in the wake of publicity suggesting that property values would drop, the Duke would hardly sell for a purpose that would result in the depreciation of the rest of his estate. $^{132}$

The extent, variety, and promulgation of protests against animal experimentation during the early part of the twentieth century, and the responses of medical scientists, deserve detailed analyses that are beyond the scope of this paper. Some of the debates outlined here suggest fascinating case studies in which to assess shifting priorities in relation to the use of animals and their relevance to humans, such as the experiences of the antivivisectionists during the First World War when arguments that had been acceptable pre-war were, in the changed circumstances, judged to be treacherous. Some antivivisectionist and animal welfare groups also displayed ambivalent "trading-down" positions with regard to dogs. The MRC's memorandum in response to the 1927 Dogs Protection Bill had emphasized, amongst other uses, the importance of using dogs in biological standardization tests. This was decried by one anti-vivisectionist organization, which claimed that rabbits could equally well be used. ${ }^{133}$ The breeding and deliberate infection of dogs and puppies in the distemper research were regularly denounced, but little protest was made at the similar treatment of ferrets; and in the 1930s as prophylactic preparations were increasingly developed, the Abolitionist relied heavily on information from huntsmen and Masters of Foxhounds about the ineffectiveness, and therefore "cruelty", of distemper vaccines, without commenting on the cruelty or otherwise of hunting.

Within the British framework of legally regulated experimental work, the distinctions made between different categories of animals in the 1876 legislation were consistently reinforced by the attempts to exempt dogs. ${ }^{134}$ This is clearly different from the American

${ }^{130)}$ See G. Wilson, 'The Brown Animal Sanatory Institution', J. Hyg., 1979, 82: 155-76; 337-51, 501-21; 83: 171-97, and E. M. Tansey, 'St Thomas's and "The Headquarters of the Physiologists": a brief history of the Brown Animal Sanatory Institution', J. Physiol., 1985, 372: 11P.

131 'Report of survey of residents in Chelsea Gardens re proposed institute, April 1894', A. W. Whalley to Council of the British Institute of Preventive Medicine, in CMAC/SA/LIS/E3. See also, H. Chick, M. Hume and M. MacFarlane, War on disease: a history of the Lister Institute, London, André Deutsch, 1971, especially ch. 2 , 'A medical research institute for Britain', pp. 28-34, and also pp. 43-7.

${ }^{1.32}$ See Chick, et al. ibid., pp. 45-6.

13.3 [Anon] Vivisection on dogs: the case for exemption on scientific grounds. A discussion in non-technical language, with particular reference to the claims of the MRC, London, C. W. Daniel, c. 1932. Signed by several medically qualified persons, the document has no clear author, but provides a lengthy denunciation of the MRC's 1927 memorandum on the use of dogs and its research work on canine distemper.

1.34 Under the 1876 Act, experiments on cats and dogs were performed and recorded under the Certificates E and EE. The former was required for procedures undertaken without anaesthesia, usually inoculation experiments. and the latter for recovery surgery. The majority of experiments in the canine distemper research would be 


\section{E. M. Tansey}

situation described by Lederer who suggests that, during the 1930s in particular, anti-vivisectionist groups developed protests against the use of dogs as a "new focus", which might then serve as a prelude to campaigns for the exemption of cats, horses, and later all animals. ${ }^{135}$ The debates reported in this paper embrace strong images of the dog, the loved companion animal, being tortured on the one hand, or protected from hideous disease on the other. ${ }^{136}$ The particular veterinary benefit of the distemper research and its political potential, recognized as early as 1923 by the Secretary of the MRC, did not go unmarked by the proponents of animal experimentation. Equally, anti-vivisectionists scorned the tactic of using animals to save animals as particularly repugnant, as they had done in an earlier period, campaigning against the Brown Animal Sanatory Institute. ${ }^{137}$ However, the direct involvement of the Field was powerful in presenting the aims and results of scientific research not only to a wider public, but was particularly important in reaching a population of animal-lovers that provided a naturally receptive constituency for anti-vivisectionist claims. ${ }^{138}$ The positive and widespread publicity achieved by the Field also ensured that the distemper work was kept to the fore during the legal debates and manoeuvrings that accompanied the repeated attempts to exempt dogs from experiments. The success of the research into the cause and prevention of canine distemper was thus a critical factor in combating several of the Bills presented to Parliament during the 1920s and 1930s. The distemper work at the National Institute for Medical Research provides yet another powerful icon-that of the despised, vilified laboratory opening its doors, and local owners happily leading their dogs into it, for inoculation with a life-saving vaccine.

included under E returns. Bearing in mind that this total also includes cats, the number of experiments in 1923 was 505 , a figure that had been consistent for nearly 20 years. By 1930 the equivalent figure was 2,359. Figures taken from respective volumes of Home Office annual returns of experiments, London, HMSO. However, almost ten times as many unwanted dogs were destroyed at the Battersea Dogs' Home.

1.35 See Lederer, op. cit., note 3 above, p. 65.

1.36 C. R. Stockard, 'My experiments with distemper: there is no questioning the fact that the scourge of dogdom is conquered', Am. Kennel Gaz., 1932, reprinted by Lederle Laboratories, NIMR Pamphlet collection P137, provides a succinct record of the disease and the impact of vaccination.

${ }^{1.37}$ For the curious conditions under which the Brown Institute was founded, see the papers by Wilson, op. cit., note 130 above.

${ }^{1.38}$ Both "sides" utilized local and national dog shows to promote their campaigns. Such shows were widely recognized as a means by which distemper was spread, and as such posed a particular health threat to puppies, see H. Ritvo, The animal estate, Cambridge, Mass., Harvard University Press, 1987, pp. 100-1. 